\title{
Antibody-Aided Clearance of Extracellular $\alpha$-Synuclein Prevents Cell-to-Cell Aggregate Transmission
}

\author{
Eun-Jin Bae, ${ }^{1,3}$ He-Jin Lee, ${ }^{2,3}$ Edward Rockenstein, ${ }^{4}$ Dong-Hwan Ho, ${ }^{1,3}$ Eun-Bi Park, ${ }^{1,3}$ Na-Young Yang, ${ }^{1,3}$ \\ Paula Desplats, ${ }^{4}$ Eliezer Masliah, ${ }^{4}$ and Seung-Jae Lee ${ }^{1,3}$ \\ ${ }^{1}$ Department of Biomedical Science and Technology, ${ }^{2}$ Department of Anatomy, School of Medicine, BK21, and ${ }^{3}$ SMART-IABS, Konkuk University, Seoul \\ 143-701, Korea, and ${ }^{4}$ Department of Neurosciences and Pathology, School of Medicine, University of California San Diego, La Jolla, California 92093-0624
}

\begin{abstract}
Abnormal deposition and intercellular propagation of $\alpha$-synuclein plays a central role in the pathogenesis of disorders such as Parkinson's Disease (PD) and dementia with Lewy bodies (DLB). Previous studies demonstrated that immunization against $\alpha$-synuclein resulted in reduced $\alpha$-synuclein accumulation and synaptic loss in a transgenic (tg) mouse model, highlighting the potential for immunotherapy. However, the mechanism by which immunization prevents synucleinopathy-associated deficits remains unknown. Here, we show that antibodies against $\alpha$-synuclein specifically target and aid in clearance of extracellular $\alpha$-synuclein proteins by microglia, thereby preventing their actions on neighboring cells. Antibody-assisted clearance occurs mainly in microglia through the Fc $\gamma$ receptor, and not in neuronal cells or astrocytes. Stereotaxic administration of antibody into the brains of $\alpha$-synuclein tg mice prevented neuronto-astroglia transmission of $\alpha$-synuclein and led to increased localization of $\alpha$-synuclein and the antibody in microglia. Furthermore, passive immunization with $\alpha$-synuclein antibody reduced neuronal and glial accumulation of $\alpha$-synuclein and ameliorated neurodegeneration and behavioral deficits associated with $\alpha$-synuclein overexpression. These findings provide an underlying mechanistic basis for immunotherapy for PD/DLB and suggest extracellular forms of $\alpha$-synuclein as potential therapeutic targets.
\end{abstract}

\section{Introduction}

Disorders with $\alpha$-synuclein accumulation such as Parkinson's disease (PD) and dementia with Lewy bodies (DLB) are common causes of movement disorders and dementia in the aging population. Recent studies have shown that, although under physiological conditions $\alpha$-synuclein is a cytosolic protein that is localized at the presynaptic site (Iwai et al., 1995; Cookson, 2009), in PD and DLB extracellular $\alpha$-synuclein released from neurons might act as a prion-like agent mediating pathological aggregate spreading that might also induce neurodegeneration and local inflammatory responses (Desplats et al., 2009; Danzer et al., 2011; Lee et al., 2010a; Hansen et al., 2011; Kordower et al., 2011). Under such circumstances, aggregated $\alpha$-synuclein is released from neuronal cells via unconventional exocytosis (Lee et al., 2005; Jang et al., 2010), perhaps in association with exosomes (Emmanouilidou et al., 2010). Moreover, $\alpha$-synuclein has been detected in human body fluids, including blood and CSF, in both healthy subjects and PD patients (El-Agnaf et al., 2003; Mollenhauer et al., 2010). This evidence suggests that extracellular $\alpha$-synuclein might play an important role in progression of PD

Received March 15, 2012; revised July 10, 2012; accepted July 18, 2012.

Author contributions: E.-J.B., H.-J.L., and S.-J.L. designed research; E.-J.B., E.R., D.-H.H., E.-B.P., and N.-Y.Y. performed research; H.-J.L., P.D., and S.-J.L. analyzed data; E.-J.B., P.D., E.M., and S.-J.L. wrote the paper.

This work was supported by the Mid-Career Research Program (2011-0016465) and the Bio \& Medical Technology Development Program (2011-0027751) through a National Research Foundation grant funded by the Korean government (Ministry of Education, Science, and Technology) (S.-J.L.). This work was also supported by National Institutes of Health Grants AG 11385, AG 18840, AG 022074, and NS 044233 (E.M.).

Correspondence should be addressed to Seung-Jae Lee, Department of Biomedical Science and Technology, Konkuk University, 1 Hwayang-dong, Gwangjin-gu, Seoul 143-701, Korea. E-mail: sjlee@konkuk.ac.kr.

DOI:10.1523/JNEUROSCI.1292-12.2012

Copyright $\odot 2012$ the authors $\quad 0270-6474 / 12 / 3213454-16 \$ 15.00 / 0$ and DLB; hence, efficient clearance of the protein might represent a potential therapeutic approach by reducing cell-to-cell transmission (Lee et al., 2010c;2011c).

We have previously shown that both active and passive immunization against $\alpha$-synuclein significantly reduced $\alpha$-synuclein deposition and synaptic loss in a transgenic (tg) model of synucleinopathy (Masliah et al., 2005b, 2011). In this study, we evaluated the hypothesis that antibodies that target extracellular $\alpha$-synuclein aid microglia in clearance of the protein, thereby preventing the spread of aggregates and their pathogenic actions.

\section{Materials and Methods}

Materials. The following antibodies were used in this study: $\alpha$-synuclein monoclonal antibody (BD Biosciences, \#610787), $\alpha$-synuclein polyclonal antibody (Cell Signaling Technology, \#2642), myc polyclonal antibody (Abcam, \#ab9106), CD32 polyclonal antibody (United States Biological, \#c2384-0B), and CD16/CD32 monoclonal antibody (Abcam, \#ab25235), GM130 monoclonal antibody (BD Biosciences, \#G65120), cathepsin D monoclonal antibody (Abcam, \#ab6313), and caveolin-1 monoclonal antibody (BD Biosciences, \#C13620). FITC-labeled cholera toxin B subunit (CTB) was purchased from Sigma. Bodipy-labeled GM1, Bodipy-FL LDL, and Alexa Fluor 568-conjugated Dextran were purchased from Invitrogen. UltraLink immobilized protein A/G, Gentle $\mathrm{Ag} / \mathrm{Ab}$ binding buffer $\mathrm{pH}$ 8.0, and gentle elution buffer for IgG purification were obtained from Pierce.

Antibody production. Detailed procedures for production and characterization of monoclonal antibodies against $\alpha$-synuclein have been described previously (Lee et al., 2011b). All antibodies against $\alpha$-synuclein are monoclonal antibodies of IgG2a isotype. The epitopes of 62 and 274 antibodies reside in the C-terminal end of $\alpha$-synuclein (120-140), while the epitopes of 169 and 171 antibodies require both the C-terminal region (120-140) and the mid-region (61-95). Species reactivity test 
showed that 169,274 , and 171 antibodies react only to human $\alpha$-synuclein, while 62 antibody is reactive to both human and mouse $\alpha$-synuclein. The antibodies used in the current study do not distinguish different forms. Especially, the 274 antibody shows the immunoreactivity against both the monomeric and the aggregated forms and both the cytoplasmic and extracellular forms of $\alpha$-synuclein. The control IgG, the mixture of mouse IgG isotypes, was prepared from the pooled normal mouse serum by using protein $\mathrm{A} / \mathrm{G}$ column.

Purification of $\alpha$-synuclein and production of fibrils and oligomers. The wild-type human $\alpha$-synuclein was purified as previously described (Lee et al., 2011a). For fibrillation, $\alpha$-synuclein ( $3 \mathrm{mg} / \mathrm{ml}$ in PBS) was incubated at $37^{\circ} \mathrm{C}$ for 2 weeks with constant shaking at $250 \mathrm{rpm}$. Following brief sonication, $\alpha$-synuclein was incubated again for 1 additional week. After incubation, the protein was centrifuged at $100,000 \times g$ for $1 \mathrm{~h}$, and the pellet was resuspended in PBS. In some experiments, small fibril fragments made by sonication were used. $\alpha$-synuclein oligomers were prepared as previously described (Danzer et al., 2007). Lyophilized $\alpha$-synuclein was dissolved in 50 mm sodium phosphate, $\mathrm{pH}$ 7.0, with $20 \%$ ethanol at a final concentration of $0.1 \mathrm{mg} / \mathrm{ml}$ and shaken at $250 \mathrm{rpm}$ at room temperature for 4 h. $\alpha$-synuclein was lyophilized again and resuspended in $1 / 2$ starting volume of $50 \mathrm{~mm}$ sodium phosphate, $\mathrm{pH} 7.0$, with $10 \%$ ethanol. The protein was incubated at room temperature for $24 \mathrm{~h}$ with the lid open to allow for evaporation of residual ethanol.

Cell culture. SH-SY5Y cells were maintained and differentiated as previously described (Lee et al., 2004). The BV-2 microglial cell line was maintained in DMEM with 5\% fetal bovine serum (FBS) and penicillin and streptomycin. Hybridoma cells were cultured in DMEM with $10 \%$ FBS and $100 \mu \mathrm{M}$ hypoxanthine supplement (Invitrogen). Rat primary glia cultures were prepared as previously described (Lee et al., 2008a). Primary cortical neurons were obtained from embryonic day 15-16 (E15-16) embryos of Sprague Dawley rats according to the procedure described previously (Lee et al., 2005).

Preparation of conditioned medium. Differentiated SH-SY5Y cells were infected with adeno/ $\alpha$-syn. On day 2 postinfection, cells were washed three times with DMEM and cultured in serum-free DMEM. After $18 \mathrm{~h}$ incubation at $37^{\circ} \mathrm{C}$, conditioned medium was collected and centrifuged at $4^{\circ} \mathrm{C}$ at $250 \times g$ for $10 \mathrm{~min}$, followed by another centrifugation of the supernatant at $4^{\circ} \mathrm{C}$ at $10,000 \times g$ for $10 \mathrm{~min}$ to remove cell debris. The supernatant was concentrated using an Amicon 10K MWCO filters (Millipore).

Uptake and degradation of $\alpha$-synuclein aggregates and monomers in cells. BV-2, microglia, and astrocytes were split into culture dishes on the day before the experiment. After washing cells twice with ice-cold PBS, $0.2 \mu \mathrm{M} \alpha$-synuclein fibrils or oligomers, pre-incubated with either 5 $\mu \mathrm{g} / \mathrm{ml}$ normal mouse IgG or $\alpha$-synuclein antibody for $5 \mathrm{~min}$ at room temperature, were added to cells with culture media. Monomers were added at $1 \mu \mathrm{M}$. Conditioned medium $(5 \times$ concentrate) was also preincubated with antibodies for $5 \mathrm{~min}$. Cells were then incubated at $37^{\circ} \mathrm{C}$ and harvested at the indicated times. For measurement of degradation rates, aggregates were internalized into cells, as above, and cells were washed twice with ice-cold PBS. Fresh culture medium was added, followed by incubation of cells at $37^{\circ} \mathrm{C}$ for the indicated times.

Internalization of $\alpha$-synuclein antibody. BV-2 cells were treated with 5 $\mu \mathrm{g} / \mathrm{ml}$ of 274 antibody or control IgG preincubated with different amounts of $\alpha$-synuclein fibrils $(0,2.66,13.3,66.5,133$, and $330 \mathrm{~nm})$. To exclude the possibility of nonspecific adsorption of 274 antibodies, 5 $\mu \mathrm{g} / \mathrm{ml}$ of 274 antibody pre-incubated with different amount of $\beta$-synuclein monomers $(0,66.5$, and $330 \mathrm{~nm})$ was added to cells. The levels of internalized antibodies were detected with anti-mouse IgG antibody.

Preparation of cell extracts. Cells were washed with PBS and lysed in extraction buffer [PBS, 1\% Triton X-100, 1\% (v/v) protease inhibitor mixture (Sigma)]. After incubation on ice for $10 \mathrm{~min}$, cell lysates were centrifuged at $16,000 \times g$ for $10 \mathrm{~min}$. Triton X-100 insoluble pellet was resuspended in the Laemmli sample buffer and sonicated briefly.

Western blotting. Western blotting was performed as previously described (Lee and Lee, 2002). Images were obtained and quantified using the Fujifilm Luminescent Image Analyzer LAS-3000 and Multi Gauge (v3.0) software (Fujifilm).
For quantification, the entire lane, from the start of the running gel to the $\alpha$-synuclein monomer band, was analyzed.

Immunofluorescence staining of cultured cells. The procedure for cell staining was performed as previously described (Lee and Lee, 2002). Briefly, cells grown on poly-L-lysine-coated coverslips were fixed in $4 \%$ paraformaldehyde in PBS and permeabilized in 0.1\% Triton X-100. Cells were incubated in blocking solution ( $5 \%$ bovine serum albumin/ $3 \%$ goat serum in PBS) before addition of primary antibodies diluted in blocking solution. After washing, cells were incubated with fluorescent dyeconjugated secondary antibodies. Nuclei were stained with TOPRO-3 iodide (Invitrogen), and coverslips were mounted onto slide glasses using antifade reagent (Invitrogen). Olympus FV1000 confocal laser scanning microscopy was used for observation of cells.

$\mathrm{Tg}$ mouse lines and intracerebral injection of antibodies. For this study, tg mice overexpressing $\alpha$-synuclein from the platelet-derived growth factor $\beta$ (PDGF- $\beta$ ) promoter (line M) were used (Masliah et al., 2000; Rockenstein et al., 2002). This model was selected because mice from this line develop $\alpha$-synuclein aggregates in both neuronal and glial cells that are distributed throughout the neocortex, hippocampus, and striatum, similar to what has been described in Lewy body disease. In these mice, $\alpha$-synuclein accumulates in the neuropil and in neuronal cell bodies in deep layers of the neocortex and the hippocampus. $\alpha$-synuclein begins to accumulate in neurons at 3 months of age with a maximum accumulation a 12 months of age. Accumulation of $\alpha$-synuclein in glial cells was seen to be most abundant in the neuropil of the striatum pyramidale and the inner molecular layer of the dentate gyrus (Rockenstein et al., 2002) beginning at 6 months of age. Therefore, in this tg mouse model, $\alpha$-synuclein pathology progresses with a quite consistent spatiotemporal order. All the procedures for animal experiments were approved by the Institutional Animal Care and Use Committee. All experiments were performed with female mice. For each experiment eight mice per group were used. A total of 32 mice were used for this experiment; of these, 16 mice were $\alpha$-synuclein tg mice and the other 16 were non-tg littermate controls ( 9 months old). Mice from each group were injected with $3 \mu \mathrm{l}$ of either nonimmune IgG control ( $n=8$ non-tg and $n=8 \alpha$-synuclein tg) or the antibody against $\alpha$-synuclein (clone $274 ; 1 \mathrm{mg} / \mathrm{ml})(n=8$ non-tg and $n=8 \alpha$-synuclein tg) into the hippocampus (using a $5 \mu$ l Hamilton syringe, $0.25 \mu \mathrm{l} / \mathrm{min}$ ). Briefly, as previously described, mice were placed under anesthesia on a Koft stereotaxic apparatus and coordinates (hippocampus: AP: $2.0 \mathrm{~mm}$, lateral $1.5 \mathrm{~mm}$, depth $1.3 \mathrm{~mm}$ ) were determined as per the Franklin and Paxinos (2008) atlas. A Hamilton syringe connected to a hydraulic system for injection of the solution was used for delivery of antibodies. To allow diffusion of the solution into brain tissue, the needle was left for an additional 5 min after completion of the injection. Mice received unilateral injections (right side) to allow for comparisons against the contralateral side. Mice survived for 4 weeks after antibody injection. An additional group of $12 \alpha$-synuclein tg mice (3 months old) received unilateral injections into the hippocampus of the antibody against $\alpha$-synuclein (clone 274; $1 \mathrm{mg} / \mathrm{ml}$ ) and were killed for analysis at 1, 7, 14, and $28 \mathrm{~d}$ postinjection. Following National Institutes of Health guidelines for the humane treatment of animals, mice were anesthetized with chloral hydrate and flush-perfused transcardially with $0.9 \%$ saline. Brains were removed and fixed in phosphate-buffered $4 \%$ paraformaldehyde, $\mathrm{pH} \mathrm{7.4,} \mathrm{at} 4^{\circ} \mathrm{C}$ for $48 \mathrm{~h}$ for neuropathological analysis.

Passive immunization and behavioral studies. A total of 32 mice were used for this experiment, of them 16 mice were $\alpha$-synuclein tg mice (line $\mathrm{M}, 10$ months old) and the other 16 were non-tg littermate controls (10 months old). From each group, mice received either nonimmune IgG control ( $n=8$ non-tg and $n=8 \alpha$-synuclein tg) or the mouse monoclonal antibody against $\alpha$-synuclein (clone $274 ; 1 \mathrm{mg} / \mathrm{ml})(n=8$ non-tg and $n=8 \alpha$-synuclein $\operatorname{tg}$ ) via intraperitoneal at a concentration of $1 \mathrm{mg} / \mathrm{ml}$ (100 $\mu \mathrm{l}$ per week for 4 weeks). Mice survived for 1 month after the first injection and then were tested for spontaneous activity in the open field and for motor function in the pole test as previously described (Masliah et al., 2000; Rockenstein et al., 2002). Following the behavioral testing, mice were subjected to neuropathological analysis.

Immunocytochemical analyses of $\alpha$-synuclein accumulation and neuropathology. Analysis of $\alpha$-synuclein accumulation was performed in serially sectioned, free-floating, blind-coded vibratome sections from non-tg 

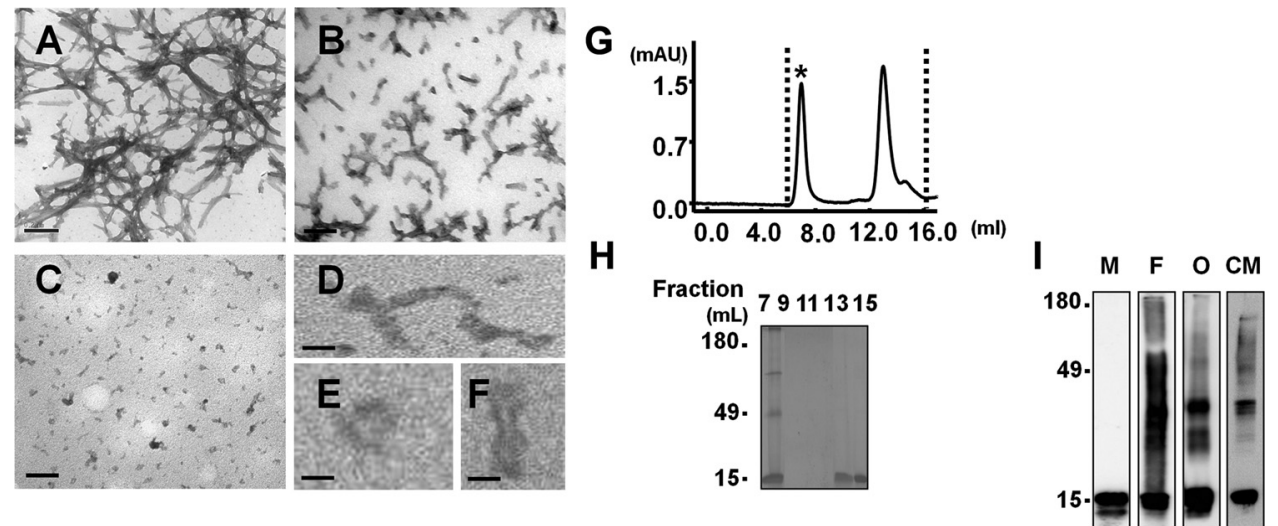

Figure 1. Characterization of $\alpha$-synuclein fibrils and oligomers. $\boldsymbol{A}-\boldsymbol{F}$, EM images of fibrils $(\boldsymbol{A})$, sonicated fibrils $(\boldsymbol{B})$, and oligomers $(\boldsymbol{C}-\boldsymbol{F})$. Scale bars: $\boldsymbol{A}-\boldsymbol{C}, 0.5 \mu \mathrm{m} ; \boldsymbol{D}-\boldsymbol{F}, 30 \mathrm{~nm}$. $\mathbf{G}$, Size exclusion chromatography of oligomers. Asterisk ( $7 \mathrm{ml}$ fraction) indicates the oligomer fraction. Monomers are present in the $13-15 \mathrm{ml}$ fractions. $\boldsymbol{H}$, Silver-staining image of the SEC fractions. I, Western blot analysis of various forms of $\alpha$-synuclein. M, monomer; F, fibril; 0 , oligomer; CM, conditioned medium of differentiated SH-SY5Y cells expressing $\alpha$-synuclein.

and $\alpha$-synuclein tg mice treated with $\operatorname{IgG}$ or the antibody against $\alpha$-synuclein (clone 274). Sections were incubated overnight at $4^{\circ} \mathrm{C}$ with an anti- $\alpha$-synuclein antibody (1:500, affinity purified rabbit polyclonal; Millipore Bioscience Research Reagents), followed by biotinylated goat anti-rabbit IgG (1:100; Vector Laboratories), Avidin D-horseradish peroxidase (1:200, ABC Elite; Vector Laboratories), and detection with diaminobenzidine (DAB). Sections were imaged with an Olympus bright-field digital microscope. For each case, three sections were analyzed by the disector method using the Stereo-Investigator System (MBF Bioscience) and the results were averaged and expressed as numbers per $\mathrm{mm}^{3}$. To analyze the effects of immunization on neurodegeneration and neuro-inflammatory responses, sections were immunolabeled with mouse monoclonal antibodies against NeuN (Millipore), glial fibrillary acidic protein (GFAP) (Millipore), Ibal (Wako), IL6 (Novus Biologicals), and tumor necrosis factor $\alpha$ (Abcam) followed by detection with DAB. Sections immunostained with antibodies GFAP and Iba-1 were imaged with an Olympus bright-field digital microscope and analyzed for optical density and cell counts with the Image Pro-Plus system. Sections immunostained with antibodies against NeuN were analyzed by the dissector method using the Stereo-Investigator System (MBF Bioscience) and the results were averaged and expressed as numbers per $\mathrm{mm}^{3}$.

Double immunocytochemical and confocal analysis. To determine the colocalization, $40-\mu \mathrm{m}$-thick vibratome sections were double labeled with combinations of antibodies against $\alpha$-synuclein (Millipore Bioscience Research Reagents, affinity purified polyclonal, 1:500), mouse IgG (to detect the 274 antibody distribution), and Iba-1 (microglial marker), as previously described (Spencer et al., 2009). The $\alpha$-synucleinimmunoreactive structures were detected with the Tyramide Signal Amplification-Direct (Red) system (1:100; NEN Life Sciences) while the mouse IgG or Iba-1 was detected with the fluorescein isothiocyanate (FITC)-conjugated horse anti-mouse antibody (1:75; Vector Laboratories).

All sections were processed simultaneously under the same conditions and experiments were performed twice to assess the reproducibility of results. Sections were imaged with a Zeiss $63 \times($ NA 1.4) objective on an Axiovert 35 microscope (Zeiss) with an attached MRC1024 LSCM system (Bio-Rad). For each section, serial optical sections in a plane of 10 $\mu \mathrm{m}$ were obtained and used for analysis of the percentage of Iba-1positive cells displaying $\alpha$-synuclein-immunoreactive material. From each case an average of 120 Iba-1-positve cells were analyzed (30 per section). Additional studies to determine the colocalization of $\alpha$-synuclein to neurons or astroglial cells after immunization were performed by double labeling sections with antibodies against NeuN (neuronal marker; Millipore, mouse monoclonal, 1:1000) or GFAP (astroglial markers; Millipore, mouse monoclonal, 1:2000) and $\alpha$-synuclein (rabbit polyclonal; Millipore, 1:5000). $\alpha$-synuclein was detected with the Tyramide Signal Amplification-Direct (Red) system (1:100; NEN Life Sciences) while NeuN or GFAP detected with the FITC.
Statistical analysis. Values shown in the figures are presented as mean \pm SEM. $P$ values for determination of the statistical significance of differences were calculated either by means of paired or unpaired, twotailed Student's $t$ test, one-way ANOVA with a post hoc Dunnet's or one-way ANOVA with Tukey's post test using GraphPad InStat version 3.05 software. For statistical analysis of the internalization kinetics data, the best-fit relative values of $\alpha$-synculein obtained from independent experiments were analyzed by extra sum-of-squares $F$ test using GraphPad InStat version 3.05 software.

\section{Results}

\section{Antibody-mediated clearance of extracellular $\alpha$-synuclein} aggregates by microglial cells

To investigate the therapeutic effects of antibodies against $\alpha$-synuclein, we generated monoclonal antibodies against human $\alpha$-synuclein (Lee et al., 2011b) and tested their effects on clearance of extracellular $\alpha$-synuclein aggregates in microglial cells.

We produced oligomers and fibrils from recombinant human $\alpha$-synuclein; electron microscopy (EM), size exclusion chromatography (SEC), and gel electrophoresis were used for confirmation of their physical properties. $\alpha$-synuclein oligomers appeared on EM as a heterogeneous mixture of globular, curvy, and short elongated structures (Fig. $1 C-F$ ). Based on SEC data, about half of the proteins in the oligomer preparation were high molecular weight oligomers, and the other half were monomers (Fig. $1 G, H)$. By silver staining and Western blotting, we found that the fibril and oligomer preparations contained both SDS-resistant aggregates (multiple high molecular weight bands) and SDSsoluble aggregates, which appear as the monomer band at $16 \mathrm{kDa}$ (Fig. $1 H, I$ ).

First, we evaluated the effects of four clones of monoclonal antibodies on uptake of $\alpha$-synuclein fibrils in BV-2 microglial cell line. Among these, two antibodies, named 169 and 274, promoted uptake, whereas the other two (62 and 171) had little effect (Fig. 2A,B). Effects of these antibodies are dose dependent and reach a saturation point (Fig. $2 C$ ). Based on this preliminary characterization, antibody 274 was selected for use in performance of the remainder of the studies. Antibody 274 is specific for human form of $\alpha$-synuclein, and the epitope lies in the $\mathrm{C}$ terminus of the protein (Lee et al., 2011b).

We compared uptake and degradation rates of $\alpha$-synuclein aggregates in the BV-2 microglial cell line in the presence of either the 274 antibody or control IgG. For uptake experiment, $0.2 \mu \mathrm{M}$ $\alpha$-synuclein aggregates pre-incubated with either $5 \mu \mathrm{g} / \mathrm{ml}$ of con- 


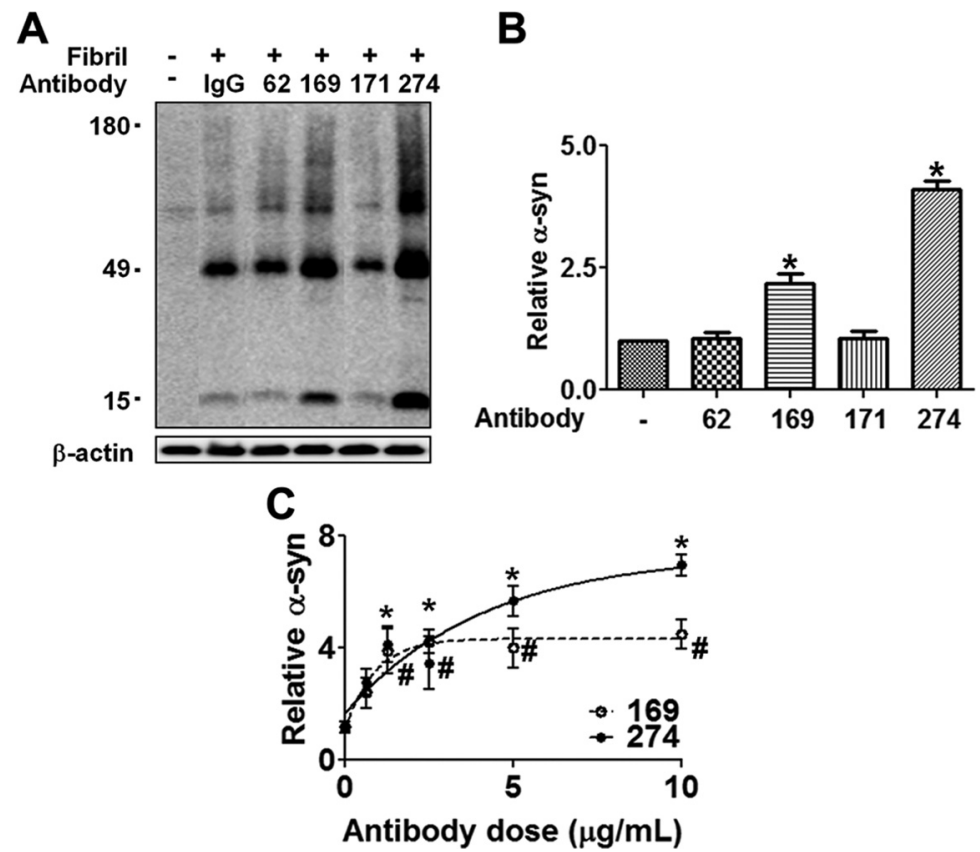

Figure 2. Effects of monoclonal antibodies on uptake of extracellular $\alpha$-synuclein aggregates. $A$, Internalization of $\alpha$-synuclein fibrils in the presence of the indicated monoclonal antibodies against $\alpha$-synuclein or control $\operatorname{lgG}(-)$ in BV-2 microglia cells. $\alpha$-synuclein fibrils $(0.2 \mu \mathrm{m})$ was pre-incubated with either $5 \mu \mathrm{g} / \mathrm{ml}$ of control lgG or antibodies against $\alpha$-synuclein for 5 min at room temperature and treated to BV-2 cells for 5 min at $37^{\circ}$. The amount of the internalized $\alpha$-synuclein was analyzed by Western blotting. $\boldsymbol{B}$, Amounts of internalized $\alpha$-synuclein were quantified and normalized by the levels of $\beta$-actin. Numbers in the $y$-axis represent the amounts of $\alpha$-synuclein relative to the control. $n=4,{ }^{*} p<0.05$. C, Antibody dose-dependent uptake of $\alpha$-synuclein fibrils $(n=3, p<0.05) *$, 274; \#, 169 .

trol IgG or 274 antibody were added to cells. Cells were incubated at $37^{\circ} \mathrm{C}$ and harvested at the indicated time. For degradation experiment, the aggregates were pre-incubated with cells for 10 and $5 \mathrm{~min}$ for fibrils and oligomers, respectively, and the cells were washed and incubated at $37^{\circ} \mathrm{C}$ in fresh culture media for the indicated times. In the presence of the 274 antibody, the time required to reach the maximum level of internalized fibrillar $\alpha$-synuclein was reduced from 30 to $10 \mathrm{~min}$ (Fig. $3 A$ ), and the half-life of imported fibrillar $\alpha$-synuclein was reduced from 77 to $11 \mathrm{~min}$ (Fig. 3B). In case of the clearance of oligomeric $\alpha$-synuclein aggregates, the time required for internalized $\alpha$-synuclein oligomers to reach the maximum level shifted from 11 to $4 \mathrm{~min}$ in the presence of the 274 antibody, and the half-life of the internalized oligomers was reduced from 18 to $6 \mathrm{~min}$ (Fig. $3 C, D$ ). On the other hand, addition of the 62 antibody (Fig. 2) had no effect on uptake and degradation rates of $\alpha$-synuclein fibrils or oligomers in BV-2 cells (data not shown), thereby suggesting that this effect is antibody specific. In contrast to fibrils and oligomers, the uptake rate for monomer was not changed by addition of the 274 antibody in microglia (our unpublished data). These results indicate that in the presence of the 274 antibody, uptake and degradation of extracellular $\alpha$-synuclein aggregates, but not monomers, are promoted in microglia.

To better reproduce the brain cellular environment, we generated the rat primary microglia culture and measured the rate at which these microglial cells take up $\alpha$-synuclein proteins that were released from neuronal cells. For this experiment, we used the conditioned medium obtained from differentiated SH-SY5Y neuroblastoma cells overexpressing human $\alpha$-synuclein. The conditioned medium contains both the monomers and SDSstable aggregates (Fig. 1I). Compared with cells treated with control IgG, uptake of neuronal cell-released $\alpha$-synuclein was faster and reached higher levels in 274 antibodytreated primary microglia (Fig. $3 E, F$ ), thereby suggesting that the antibody aided microglia in clearance of neuron-released extracellular $\alpha$-synuclein.

We have previously shown that in addition to microglia, neurons and astroglia can take up extracellular $\alpha$-synuclein aggregates and degrade them (Lee et al., 2008a). Consistent with the previous study, the current studies showed that microglia is the fastest in uptake and degradation of $\alpha$-synuclein aggregates, followed by astrocytes, and neurons are the slowest. We next examined the effects of the 274 antibody on uptake and degradation rates of exogenous $\alpha$-synuclein fibrils in rat primary astrocytes and cortical neurons as well as differentiated SH-SY5Y human neuroblastoma cells. In contrast to microglia, no change of either uptake or degradation rate of extracellular $\alpha$-synuclein fibrils was observed in these cells (Fig. 4A-F). Likewise, uptake of monomer was not affected by the antibody in astrocytes or neurons (our unpublished data). Therefore, antibodymediated clearance of extracellular $\alpha$-synuclein appears to be a process selective for microglia and only applicable to aggregates, not monomers.

\section{Antibody-assisted clearance of $\boldsymbol{\alpha}$-synuclein aggregates is mediated by $\mathrm{Fc} \gamma$ receptor, resulting in faster delivery to lysosomes}

Fc $\gamma$ receptors are cell surface receptors that recognize Fc domains of IgG and trigger a wide variety of immune effector functions, including phagocytosis, antibody-dependent cellular cytotoxicity, release of inflammatory mediators, and immune complex clearance (Gessner et al., 1998). To evaluate the role of Fc $\gamma$ receptors in antibody-mediated $\alpha$-synuclein clearance, Fc $\gamma$ receptors were inhibited by incubation with a monoclonal antibody against CD16/CD32, which blocks mouse Fc $\gamma$ receptors II and III (Wijngaarden et al., 2005). Blockage of Fc $\gamma$ receptors eliminated the effect of 274 antibody on uptake of $\alpha$-synuclein oligomers (Fig. $5 A)$. Fc $\gamma$ receptors colocalized with oligomeric $\alpha$-synuclein on the surface of BV-2 cells only in the presence of 274 antibody, not in the presence of control IgG or the Fab fragment of 274 antibody (Fig. 5B), further validating involvement of Fc $\gamma$ receptors in the uptake process. Fc $\gamma$ receptors showed significant expression in BV-2 microglia cells and rat primary microglia, but were not detected in astrocytes or differentiated neuroblastoma cells (Fig. 5C).

Type II and type III (CD32/CD16) Fc $\gamma$ receptors are low-affinity receptors for IgG and require multivalent antigen-antibody complex for high-avidity binding (Ravetch and Bolland, 2001; Radaev and Sun, 2002). Therefore, antibody alone cannot bind these Fc $\gamma$ receptors with high affinity. The antibody can stably interact with the receptors only when the antibodies are "aggregated" through complex formation with multivalent antigen, such as protein aggregates. To confirm the uptake of $\alpha$-synuclein-antibody immune complexes, control IgG or the monoclonal antibody 274 was preincubated with different amounts of $\alpha$-synuclein fibrils and added to 
A

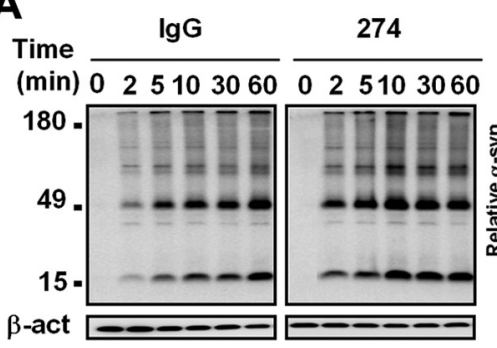

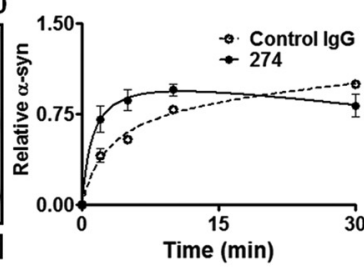

C

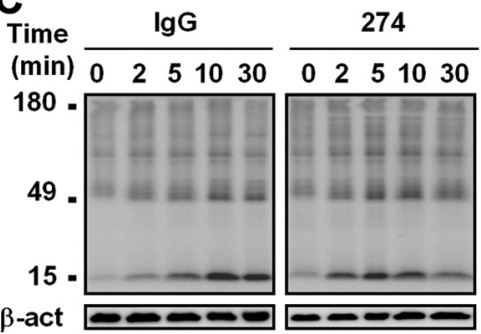

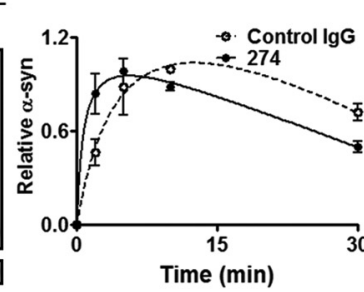

E

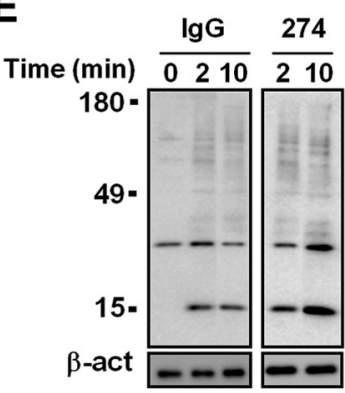

B
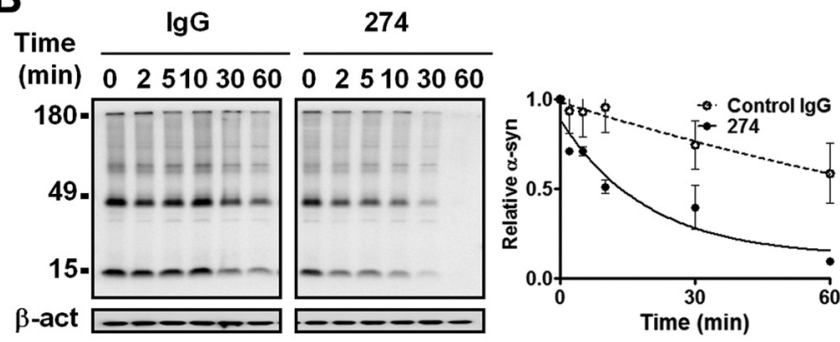

D

Time

$\lg \mathbf{G}$

274

(min) $\overline { 0 2 5 1 0 3 0 6 0 } \longdiv { 0 2 5 1 0 3 0 6 0 }$
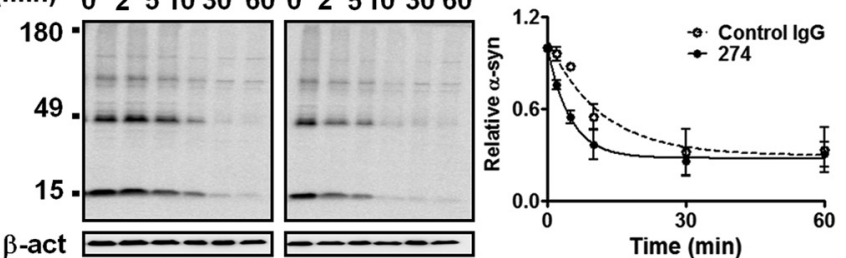

$\mathbf{F}$

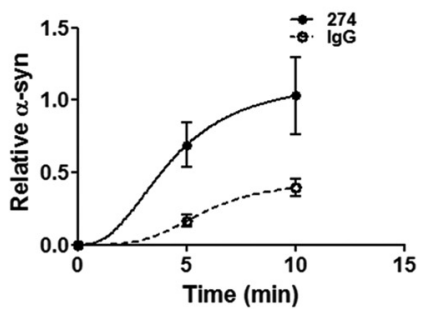

Figure 3. Effects of the 274 antibody on uptake and degradation of extracellular $\alpha$-synuclein in microglia. $A-D$, Rates of uptake $(A, C)$ and degradation $(B, D)$ of $\alpha$-synuclein fibrils $(A, B)$ and oligomers ( $C, D)$ in BV-2 cells. Internalized $\alpha$-synuclein aggregates were analyzed by Western blotting at the indicated times. Graphs in $A$ and $C$ indicate the amounts of $\alpha$-synuclein relative to the maximum internalized levels with control lgG. Graphs in $\boldsymbol{B}$ and $\boldsymbol{D}$ indicate the amounts of $\alpha$-synuclein remaining relative to those at time 0 . All values were normalized to $\beta$-actin. Curves in each graph are significantly different $(n=4, p<$ $0.05) . E, F$, Effects of the 274 antibody on uptake of neuron-released $\alpha$-synuclein in primary microglia. $E$, Primary rat microglia were treated with conditioned medium containing $\alpha$-synuclein released from differentiated SH-SY5Y cells in the presence of control lgG or 274 antibody. $F$, Quantitative analysis of the data in $E$. Curves are significantly different $(p<0.05, n=3)$. Control blot: $\beta$-tubulin.

BV-2 cells. Levels of internalized antibodies were directly proportional to the amounts of exogenous $\alpha$-synuclein aggregates (Fig. $5 D)$. Control IgG pre-incubated with $\alpha$-synuclein was not internalized by the cells, nor was the 274 antibody pre-incubated with $\beta$-synuclein internalized (Fig. 5D). Furthermore, immunofluorescence analysis showed a significant increase in antibody uptake in the presence of exogenous $\alpha$-synuclein aggregates, and colocalization of antibodies with $\alpha$-synuclein was evident in the cytoplasm after internalization (Fig. 5E,F). Collectively, these results suggest specific internalization of $\alpha$-synuclein-antibody complexes into microglial cells.

We next examined the intracellular trafficking route of $\alpha$-synuclein-antibody immune complex in comparison with the route undertaken by $\alpha$-synuclein alone. For this purpose, we used fluorescence-labeled low-density lipoprotein (LDL), as a marker of clathrin-mediated endocytosis, and cholera toxin B subunit (CTB), which serve as markers for lipid raftmediated endocytosis (Sharma et al., 2004). In the presence of control antibody, internalized $\alpha$-synuclein aggregates alone did not colocalize extensively with any of the markers (Fig. $6 A)$, suggesting a novel mechanism of trafficking. However, when $\alpha$-synuclein aggregates were applied together with the 274 antibody, a large portion of internalized $\alpha$-synuclein aggregates was found to colocalize with CTB (Fig. 6A). This is consistent with the fact that when bound to immune complexes, Fc $\gamma$ receptors are clustered in the lipid rafts (Barabé et al., 2002; Kwiatkowska et al., 2003; Rollet-Labelle et al., 2004).

To confirm these results, we conducted immunolocalization experiments. Internalized $\alpha$-synuclein aggregates did not colocalize with GM130, a marker for Golgi apparatus, indicating the lack of overlap with the biosynthetic pathway (our unpublished data). On the other hand, when incubated with 274 antibody, $\sim 38.6 \%$ of internalized $\alpha$-synuclein aggregates were found in the compartments positive for caveolin-1, whereas in the presence of control IgG, they hardly colocalized with caveolin-1 (Fig. 6B, C). This is consistent with the finding that the 274 antibody alters the trafficking pathway of internalized $\alpha$-synuclein to that undertaken by CTB (Fig. 6A). Changes in trafficking pathway resulted in the increased colocalization with lysosomes; in the presence of 274 antibody, colocalization of $\alpha$-synuclein with lysosomal marker, cathepsin D, increased from 28 to $93 \%$ (Fig. 6D,E). Collectively, these results suggest that when complexed with the antibody, $\alpha$-synuclein aggregates are internalized through Fc $\gamma$ receptors, undergo different intracellular trafficking pathways, and are delivered to lysosomes more efficiently than free $\alpha$-synuclein aggregates, which may account for faster degradation. 

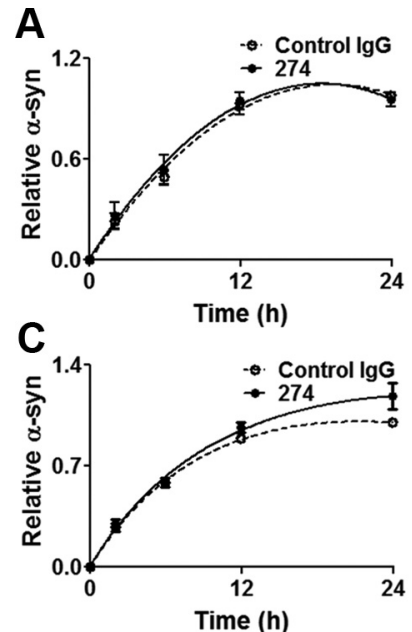

B
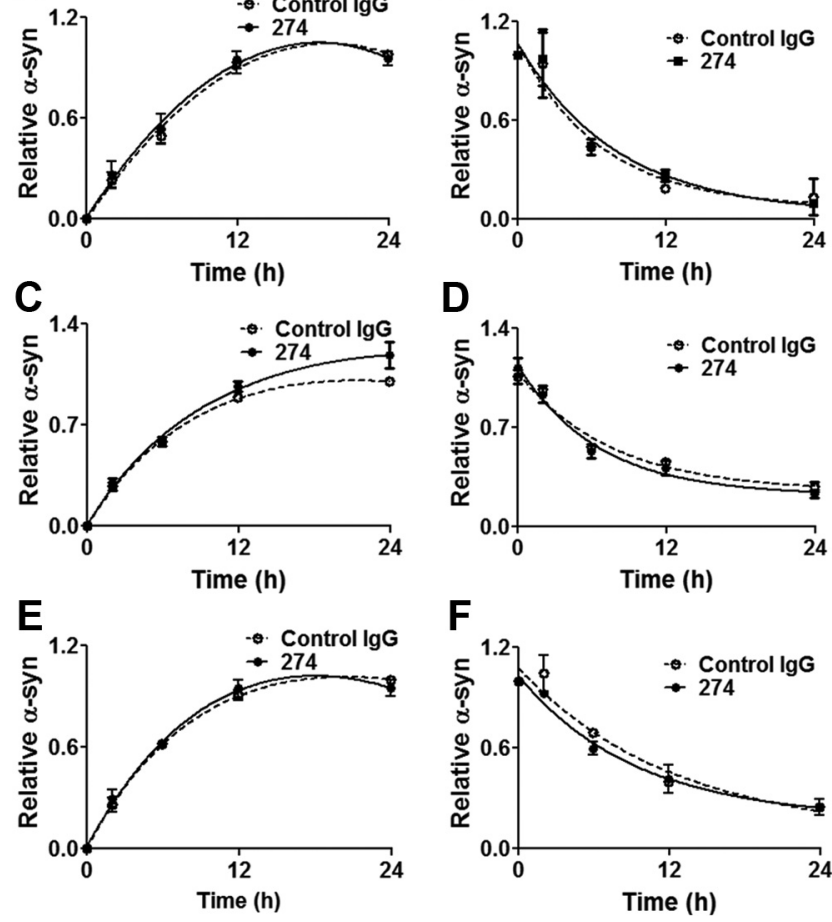

$D$
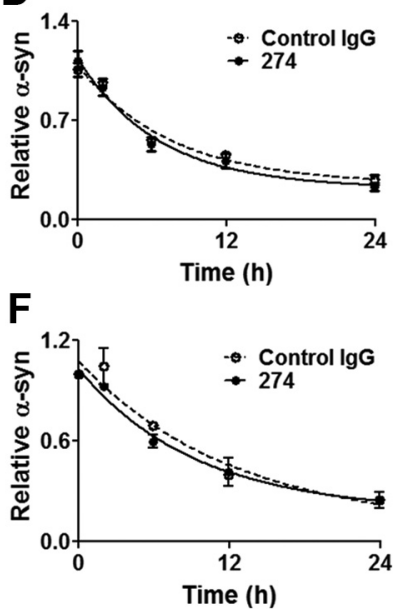

Figure 4. Lack of effects of the 274 antibody on uptake and degradation of $\alpha$-synuclein fibrils in primary astrocytes and neuronal cells. $\boldsymbol{A}, \boldsymbol{B}$, Primary astrocyte $(n=4)$. $\boldsymbol{C}, \boldsymbol{D}$, Primary cortical neuron $(n=3)$ ). $\boldsymbol{E}, \boldsymbol{F}$, Differentiated SH-SY5Y cell $(n=4)$. $\boldsymbol{A}, \boldsymbol{C}, \boldsymbol{E}$, Uptake rates. Graphs indicate the amounts of $\alpha$-synuclein relative to the maximum internalized levels with control $\lg$ G. $\boldsymbol{B}, \boldsymbol{D}, \boldsymbol{F}$, Degradation rates. Graphs indicate the amounts of $\alpha$-synuclein remaining relative to those at time 0 . Pre-incubation time with $\alpha$-synuclein fibrils is $12 \mathrm{~h}(\boldsymbol{B}, \boldsymbol{D}, \boldsymbol{F})$. All the $\alpha$-synuclein data were normalized with $\beta$-actin data. Curves in graphs are not significantly different.

The 274 antibody reduces the cell-to-cell transfer of $\alpha$-synuclein, the behavioral deficits, and neurodegenerative pathology in a tg mouse model

We recently demonstrated the transfer of $\alpha$-synuclein aggregates released from neurons to neighboring neurons and astrocytes, inducing formation of pathological protein deposits in recipient cells (Desplats et al., 2009; Lee et al., 2010a). To determine whether antibody-assisted clearance of extracellular $\alpha$-synuclein aggregates might prevent this intercellular aggregate transmission, we injected the 274 antibody into the hippocampus of $t g$ mice expressing human $\alpha$-synuclein and analyzed the extent of neuron-to-astrocyte transmission of $\alpha$-synuclein proteins. It had been shown that the PDGF $\beta$ - $\alpha$-synuclein tg mice expressed human $\alpha$-synuclein in neuronal cells (Lee et al., 2010a); therefore, using an antibody specific for human $\alpha$-synuclein, one can follow the transfer of neuron-derived $\alpha$-synuclein by immunohistochemistry. Injection of control IgG did not show any effect on neuron-to-astrocyte $\alpha$-synuclein transfer; both ipsilateral and contralateral sides of the hippocampus showed the same extent of astroglial $\alpha$-synuclein accumulation (Fig. $7 A, E, K$ ). On the contrary, injection of 274 antibody resulted in significant reduction of astroglial accumulation of $\alpha$-synuclein at the ipsilateral side (Fig. $7 B, F, L$ ). Injection of antibodies did not affect $\alpha$-synuclein expression in neurons (Fig. $7 C, D$ ), nor did it alter the number of astrocytes (Fig. 7G,H), thus suggesting that antibody treatment prevents cell-to-cell transfer of $\alpha$-synuclein. Injection of control IgG did not show any effect on microglial cells (Fig. 7I); however, both ipsilateral and contralateral sides of the hippocampus in- jected with the 274 antibody showed a mild increase in microglial activation (Fig. $7 \mathrm{~J}$ ).

To confirm involvement of microglia in the blockade of cell-tocell transfer, we examined localization of human $\alpha$-synuclein and 274 antibody in microglia using double immunofluorescence staining. The number of microglial cells containing human $\alpha$-synuclein showed a significant increase at the ipsilateral side in tg mice injected with the 274 antibody (Fig. 8A,B). Injected antibodies were also detected in microglia at the ipsilateral side in tg mice injected with the 274 antibody (Fig. $8 C, D$ ), but not in mice injected with control IgG (Fig. 8D). Colocalization of human $\alpha$-synuclein and the injected antibody was consistently observed in tg mice injected with the 274 antibody (Fig. $8 E$ ), but not in mice injected with control IgG. These results suggest that $\alpha$-synuclein antibody prevents cell-to-cell transfer of $\alpha$-synuclein aggregates by promoting clearance of neuronderived $\alpha$-synuclein by microglia.

To evaluate the kinetics for microglia-assisted clearance of the $\alpha$-synuclein following the injection with the 274 antibody, double labeling with an antibody against $\alpha$-synuclein and Iba- 1 was performed at various time points (Fig. $8 F$ ). At $1 \mathrm{~d}$ post injection, $\sim 20 \%$ of the microglia displayed $\alpha$-synuclein deposits, while at 7 and $14 \mathrm{~d} \sim 10 \%$ of the microglia had $\alpha$-synuclein, which was down to $\sim 5 \%$ at day 28 (Fig. $8 G$ ).

To confirm that the 274 antibody interferes with the transfer of $\alpha$-synuclein from neurons and astroglial cells, double-labeling studies were performed with NeuN and GFAP antibodies. Confocal-assisted image analysis showed that $\alpha$-synuclein that colocalized to pyramidal shaped NeuN-positive neurons represented $\sim 20 \%$ of the cells (Fig. $8 H$ ), no significant differences between IgG and 274 antibody groups were observed (Fig. 8 I). In contrast $\alpha$-synuclein-positive cells with a spindle shape did not colocalized with NeuN, but rather with GFAP (Fig. $8 J$ ). Approximately $15 \%$ of the GFAP cells contained $\alpha$-synuclein in the control. However, treatment with the 274 antibody resulted in a reduction of the GFAP/ $\alpha$-synuclein-positive cells in the site of the injection (Fig. $8 \mathrm{~K}$ ).

The image analysis of GFAP and Iba-1-positive cells was performed in the hippocampus, below the site of the needle track to avoid the nonspecific effects of the scarring along the track. There is indeed evidence of astrogliosis along the needle track that is persistent 4 weeks after the injection. In contrast, the microglial reaction along the tract is transient and started to decrease after 2 weeks. Likewise in the hippocampus (below the injection tract) the number of activated microglia containing $\alpha$-synuclein decreases over time (Fig. $8 F, G$ ). When we examined the injection site along the tract in the IgG and 274 groups, we found some scattered astroglial cells containing $\alpha$-synuclein presumably from the disrupted neuropil (data not shown). However, we do not believe that the scarring or mechanical effect of the injection is a major driver of the clearance of the $\alpha$-synuclein; rather this is related to the presence of the 274 antibody as was further demonstrated by the passive immunization experiment (see below).

To further evaluate the effects of antibody-assisted clearance of extracellular $\alpha$-synuclein aggregates on functional and neuropathological parameters, passive immunization experiments were performed by intraperitoneal injection of control IgG or the 274 antibody into non-tg and tg mice. Analysis of functional motor coordination in the pole test showed that compared with IgG and 274-treated non-tg, the IgG-treated tg mice took a longer time to complete the paradigm (Fig. 9A). In contrast, tg mice treated with the 274 antibody performed similarly to the non-tg group (Fig. 9A). In the open field, the IgG-treated tg mice displayed some hyperactivity compared with non-tg (Fig. 9B). This 
A

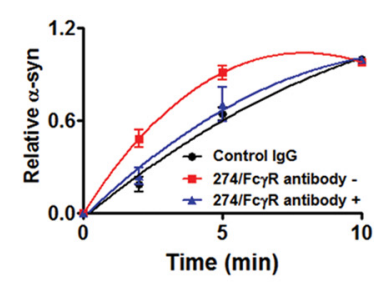

D

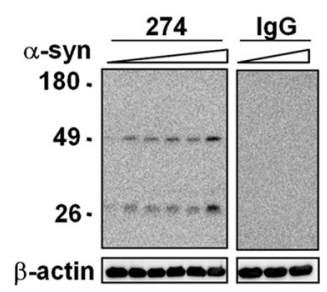

B

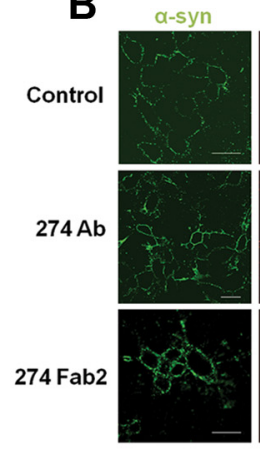

E

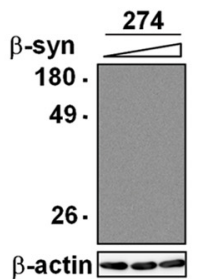

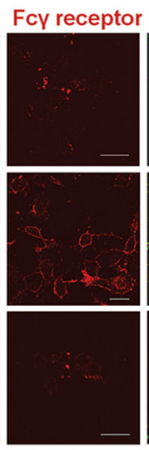
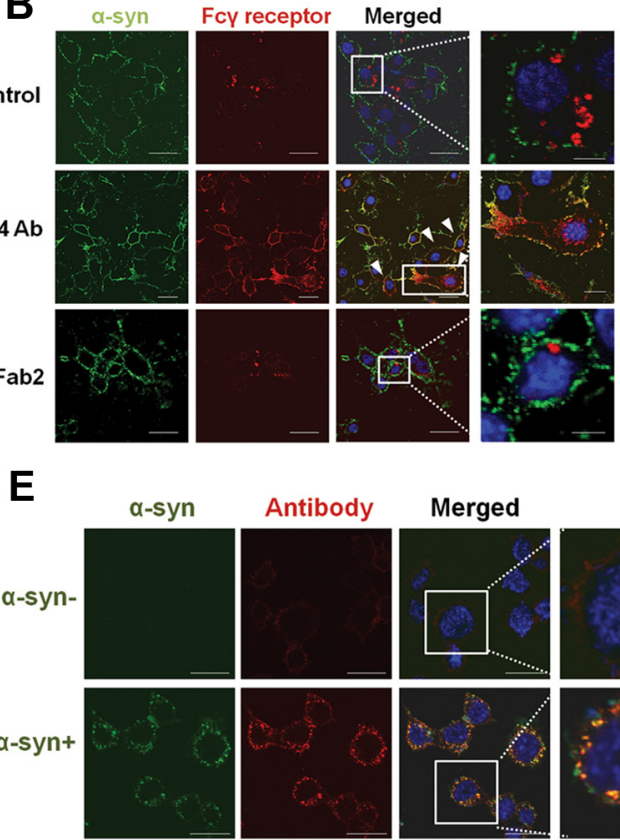
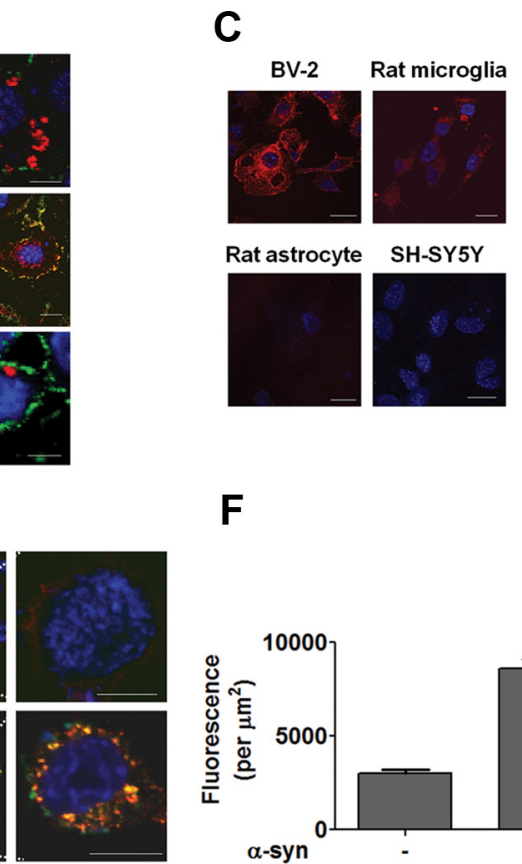

$\mathbf{F}$

Figure 5. Role of $\mathrm{F} c \gamma$ receptors in uptake of $\alpha$-synuclein-antibody immune complex. $A$, Effects of $\mathrm{F} c \gamma$ receptor blocking antibodies on the internalization of $\alpha$-synuclein oligomers in BV- 2 cells. Internalized $\alpha$-synuclein oligomers were analyzed by Western blot, and values were normalized to $\beta$-actin. The $y$-axis of the graph indicates the amounts of $\alpha$-synuclein relative to the maximum internalized level with control lgG. The red curve is significantly different from the others $(n=7, p<0.05)$. $\boldsymbol{B}$, Immunofluorescence imaging of $\mathrm{Fc} \gamma$ receptors and $\alpha$-synuclein. Arrowheads indicate cells showing colocalization of $\alpha$-synuclein and Fc $\gamma$ receptors on the surface of cells. Scale bars: $20 \mu \mathrm{m}$. C, Expression of Fc $\gamma$ receptor in various cell types. For BV-2, rat microglia, and rat astrocytes, an anti-CD16/CD32 antibody that is specific to rodent species was used, whereas for SH-SY5Y, an anti-CD32 antibody specific to the human protein was used. Note that expression of CD32 has not been reported in neurons in the brain in the previous studies. Red, Fc $\gamma$ receptor; blue, nucleus. Scale bars: $20 \mu \mathrm{m}$. $\boldsymbol{D}$, Internalization of antibodies into BV-2 cells in the presence of different amounts of $\alpha$-synuclein fibrils or $\beta$-synuclein $(0-330 \mathrm{~nm})$. Internalized antibodies were analyzed with anti-mouse IgG antibody. The bottom panels are $\beta$-actin. $E$, Immunofluorescence microscopy of internalized $\alpha$-synuclein fibrils and antibodies in BV-2 cells. Scale bars: $20 \mu \mathrm{m}$. $\boldsymbol{F}$, Fluorescence from the internalized antibodies in $\boldsymbol{E}$ was quantified. One hundred and fifty cells were analyzed from three independent experiments (50 cells per each experiment). ${ }^{*} p<0.0001$.

effect in the $\alpha$-synuclein tg mice was reversed by treatment with the 274 antibody (Fig. 9B). Other activities in the open field including total distance and rearing were not different among the four groups (Fig. 9C,D).

With a cross-species polyclonal antibody, $\alpha$-synuclein immunostaining was limited to the neuropil in the non-tg mice with no differences observed between the control IgG and the 274 antibody groups (Fig. $9 E-G$ ). In the IgG-treated $\alpha$-synuclein tg mice, there was extensive accumulation of $\alpha$-synuclein (Fig. $9 E$ ) in astroglial (Fig. 9F) and neuronal cells (Fig. 9G) in the neocortex (Fig. 9H) and hippocampus (Fig. 9I). In contrast, $\alpha$-synuclein tg mice treated with the 274 antibody (Fig. 9E) displayed a considerable reduction in the accumulation of astroglial (Fig. $9 F$ ) and neuronal $\alpha$-synuclein (Fig. 9G) in the neocortex (Fig. 9H) and hippocampus (Fig. 9I).

We also analyzed the striatum of the passively immunized mice, and we found that levels of $\alpha$-synuclein were reduced to a lower extent when compared with the cortex and hippocampus. While in the cortex and hippocampus, 274 reduced levels of $\alpha$-synuclein by $70-80 \%$ (Fig. $9 H, I$ ); in the striatum, the levels were reduced $30-35 \%$ (Fig. $9 J$ ), suggesting the differential regional trafficking of the antibody.

We performed ELISA for $\alpha$-synuclein in the brains and CSF of the control and antibody-treated $\alpha$-synuclein mice. In the brain homogenates of the $\alpha$-synuclein tg mice that were vehicle treated, the levels of $\alpha$-synuclein were $13.57 \pm 1.610 \mathrm{ng} / \mathrm{ml}(n=8)$, while in $\alpha$-synuclein tg treated with the 274 antibody were $5.031 \pm$ $1.011 \mathrm{ng} / \mathrm{ml}(n=8)$. However, the levels of $\alpha$-synuclein in the CSF were very low, under the detection limit of our ELISA system. The $\alpha$-synuclein-containing microglia were observed pri- marily in the neuropil, and very few were observed around blood vessels.

To further evaluate the effects of the 274 antibody on clearance of $\alpha$-synuclein in the passive immunization scheme, double-labeling studies were performed with antibodies against NeuN, GFAP, and Iba-1. Confocal image analysis showed that the proportion of pyramidal-shaped NeuN-positive cells that displayed $\alpha$-synuclein immunoreactivity was reduced in the group injected with the 274 antibody (Fig. $9 K, L$ ). Moreover, compared with $\alpha$-synuclein tg mice treated with IgG, treatment with the 274 antibody resulted in a reduction of the spindle-shaped GFAPpositive astroglial cells that contained $\alpha$-synuclein (Fig. $9 M, N$ ). In contrast, compared with $\alpha$-synuclein tg mice immunized with IgG alone, treatment with the 274 antibody resulted in an increase of Iba-1-positive microglial cells that contained $\alpha$-synuclein (Fig. 9O,P). We also performed double-labeling analysis for $\alpha$-synuclein and cathepsin D and found colocalization between the two markers in microglial cells of animals immunized with 274 (Fig. 9Q,R).

To study the effects of the passive immunization on neurodegenerative and neuroinflammatory pathology, immunocytochemical and image analyses were performed. With an antibody against NeuN, compared with the non-tg controls, the IgG-treated $\alpha$-synuclein tg mice displayed a reduction in the stereological neuronal cell estimates in the hippocampus (Fig. 10A,B). The loss of neuron was apparent in the CA3 region of the hippocampus (Fig. $10 \mathrm{~A}$, arrows), which had been previously reported (Price et al., 2010). In contrast, $\alpha$ synuclein tg mice treated with the 274 antibody displayed hippocampal NeuN cell counts comparable to the non-tg control 
A
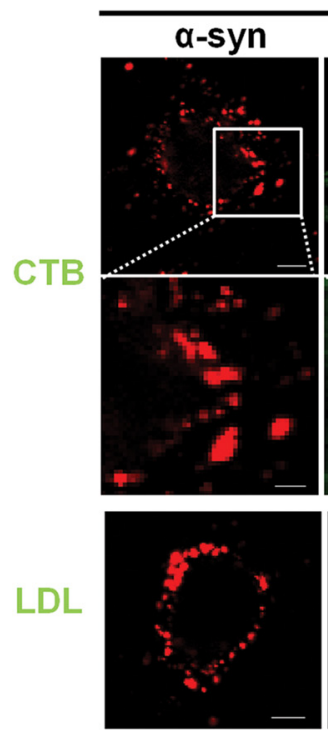

B

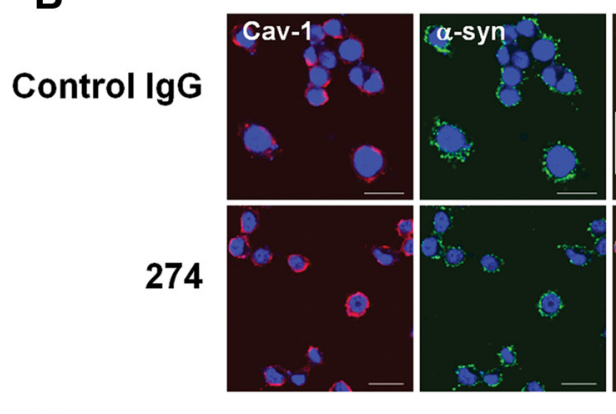

D

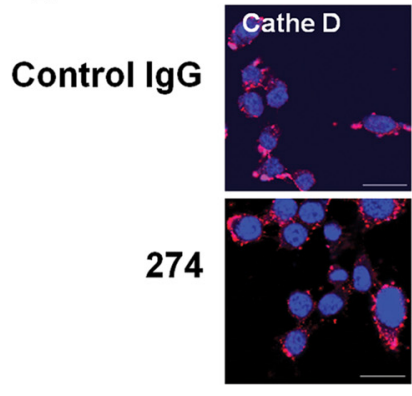

IgG
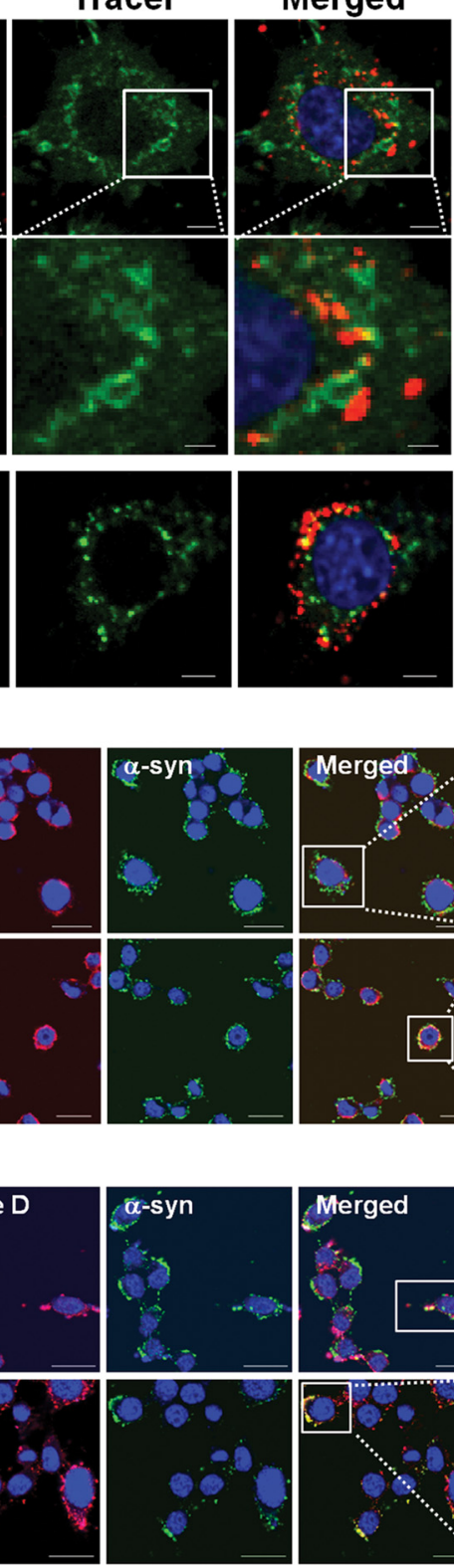

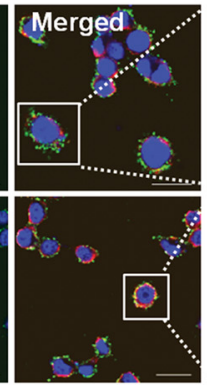

\section{Merged}
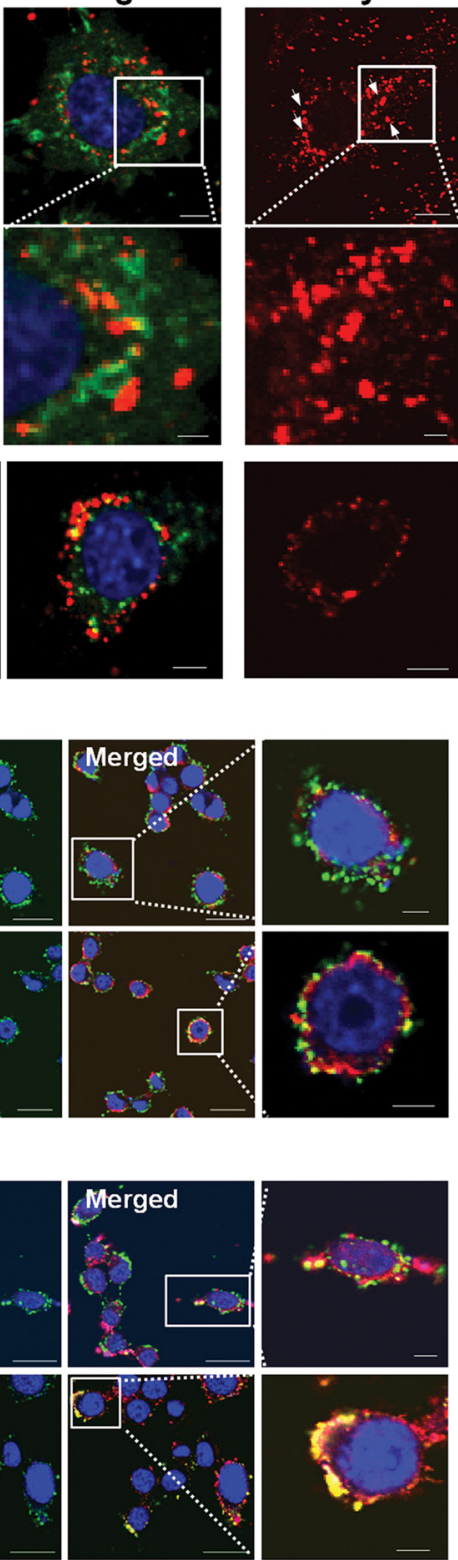

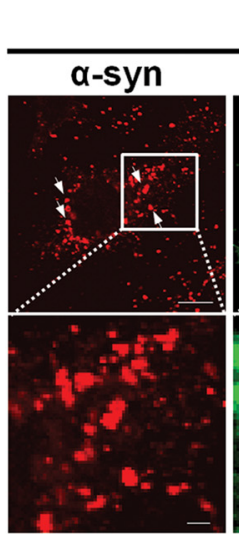

274
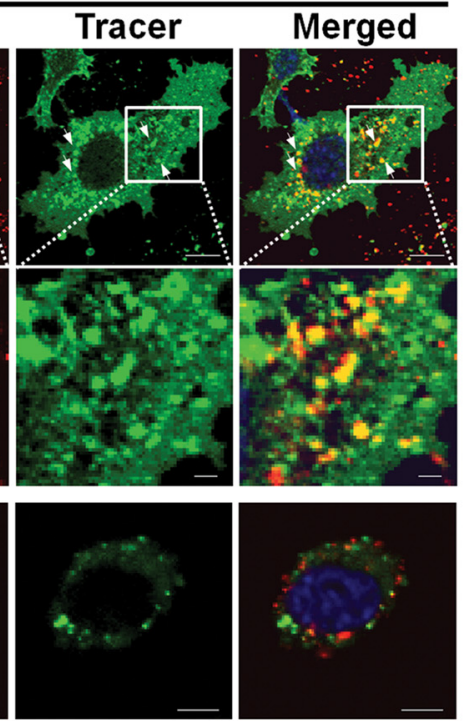

C

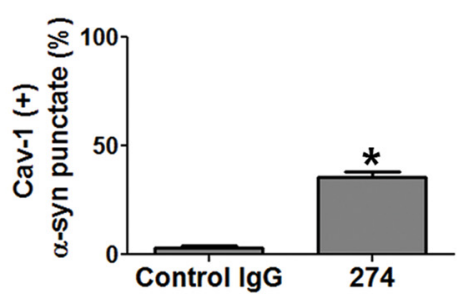

E

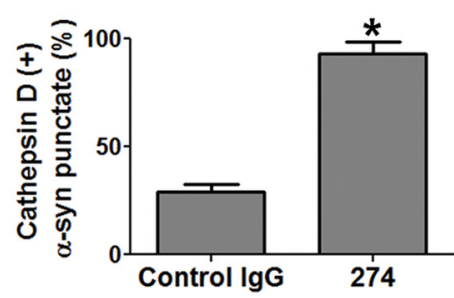

Figure 6. Altered intracellular trafficking of internalized $\alpha$-synuclein aggregates and increased delivery to lysosomes. A, Altered intracellular trafficking of internalized $\alpha$-synuclein fibrils in BV-2 cells. The fluorescence-labeled tracers were treated to BV-2 microglia cells with either control lgG- $\alpha$-synuclein mixture or $\alpha$-synuclein-274 immune complex for 5 min at $37^{\circ} \mathrm{C}$. Arrows indicate colocalization between $\alpha$-synuclein and CTB in the presence of the 274 antibody. Scale bars: $5 \mu \mathrm{m}$. $\boldsymbol{B}-\boldsymbol{E}$, Localization of internalized $\alpha$-synuclein aggregates in the endocytic compartments. The immune complexes were treated to BV-2 cells for 5 min. $\boldsymbol{C}, \boldsymbol{E}$, The number of $\alpha$-synuclein puncta colocalized with caveolin-1 (C) and cathepsin D $(\boldsymbol{E})$ was quantified. Three thousand puncta were analyzed from three independent experiments (1000 puncta per each experiment). Scale bars: $5 \mu \mathrm{m}$. ${ }^{*} p<0.005$.

(Fig. 10A,B). Synaptic changes have also been analyzed. We found a $28 \%$ reduction in synaptophysin in the IgG-treated tg, and these synaptic deficits were significantly ameliorated by the treatment with the 274 antibody (Fig. 10C,D). Immunocytochemistry with an antibody against GFAP showed that compared with the non-tg controls, $\alpha$-synuclein tg mice displayed increased astrogliosis in the deeper layers of the neocortex (Fig. 10E, inset) and in the hippocampus (Fig. 10E, F). Passive immunization with the 274 antibody reduced the levels of GFAP immunoreactivity in the neocortex (Fig. $10 \mathrm{E}$, inset) and hippocampus (Fig. 10E,F) in the $\alpha$-synuclein tg mice. Finally, with an antibody against the microglial marker,
Iba-1, similar levels of microglial cell counts were detected between the non-tg mice treated with IgG and the 274 antibody as well as in the $\alpha$-synuclein tg mice treated with IgG control (Fig. 10G). However, $\alpha$-synuclein tg mice treated with the 274 antibody displayed a moderate increase in the levels of Iba-1 immunostaining (Fig. 10G,H). In agreement with these findings, while $\alpha$-synuclein tg mice treated with IgG alone displayed increased levels of the pro-inflammatory cytokines, TNF $\alpha$ (Fig. 10I,J), and IL-6 (Fig. $10 \mathrm{~K}, L$ ), immunization with the 274 antibody reduced the levels down to baseline. This result is consistent with the conclusion that the 274 antibody promotes the clearance of extracellular $\alpha$-synuclein. 


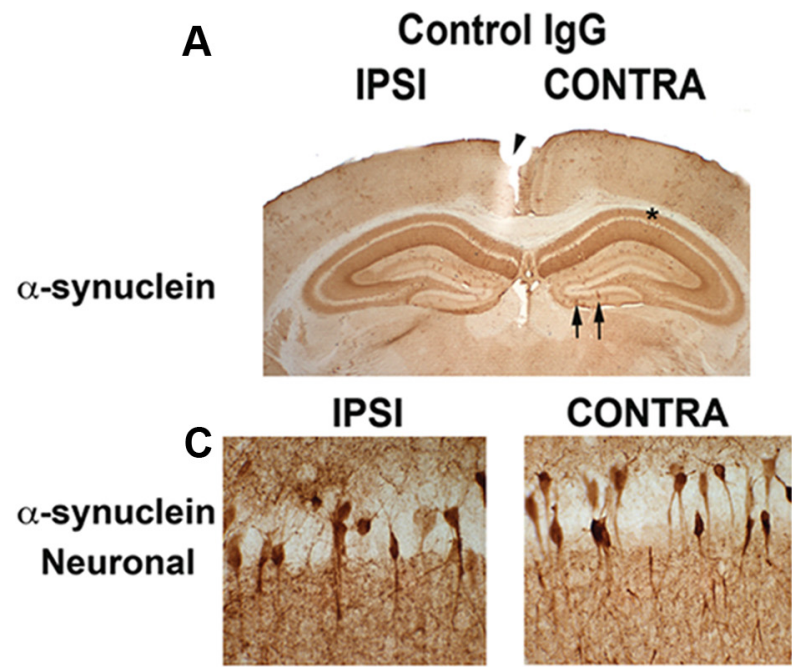

\section{B Anti- $\alpha$-syn antibody treatment IPSI CONTRA}
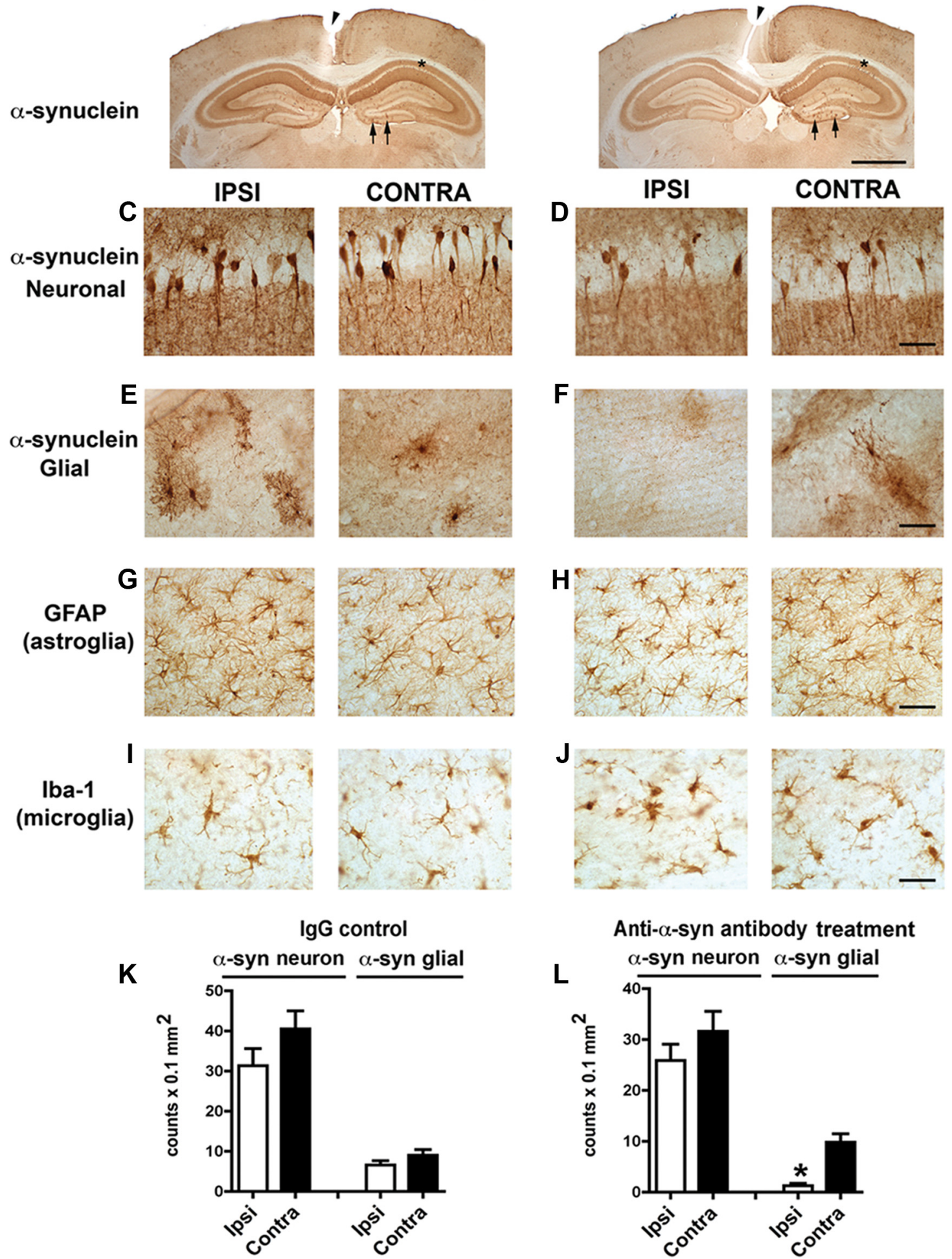

\section{Anti- $\alpha$-syn antibody treatment}

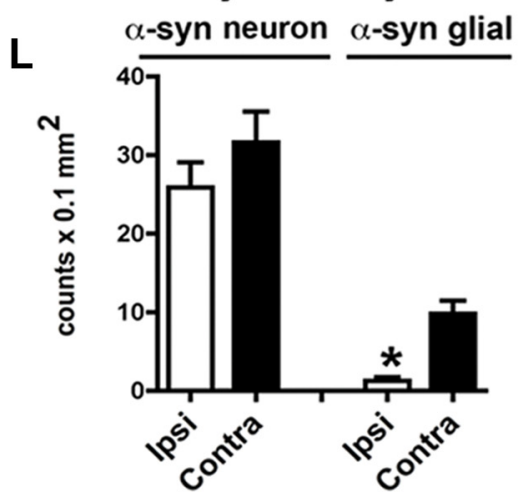

Figure 7. Reduced neuron-to-astrocyte transfer of $\alpha$-synuclein in vivo after unilateral injection of the 274 antibody. $A, B$, Low-power (20X) view of the cortex and hippocampus of PDGF- $\alpha$ synuclein tg mice (line M) comparing patterns of $\alpha$-synuclein immunoreactivity. Scale bar: $200 \mu \mathrm{m}$. $\boldsymbol{C}-\boldsymbol{J}$, Higher power view (200X) of the hippocampus CA1 region showing $\alpha$-synuclein accumulation in neurons $(\boldsymbol{C}, \boldsymbol{D})$ and the dentate gyrus region $(\boldsymbol{E}-\boldsymbol{J})$ showing $\alpha$-synuclein accumulation in glial cells $(\boldsymbol{E}, \boldsymbol{F})$, the presence of GFAP astroglial cells $(\boldsymbol{G}, \boldsymbol{H})$, and the presence of Iba1 microglial cells $(\boldsymbol{I}, \boldsymbol{J})$. Scale bar: $25 \mu \mathrm{m} . \boldsymbol{K}, \boldsymbol{L}$, Image analysis of the numbers of $\alpha$-synuclein-positive neurons and glial cells. $n=8$ per group, 9 months old. ${ }^{*} p<0.01$ by two-tailed Student's $t$ test, unpaired. 

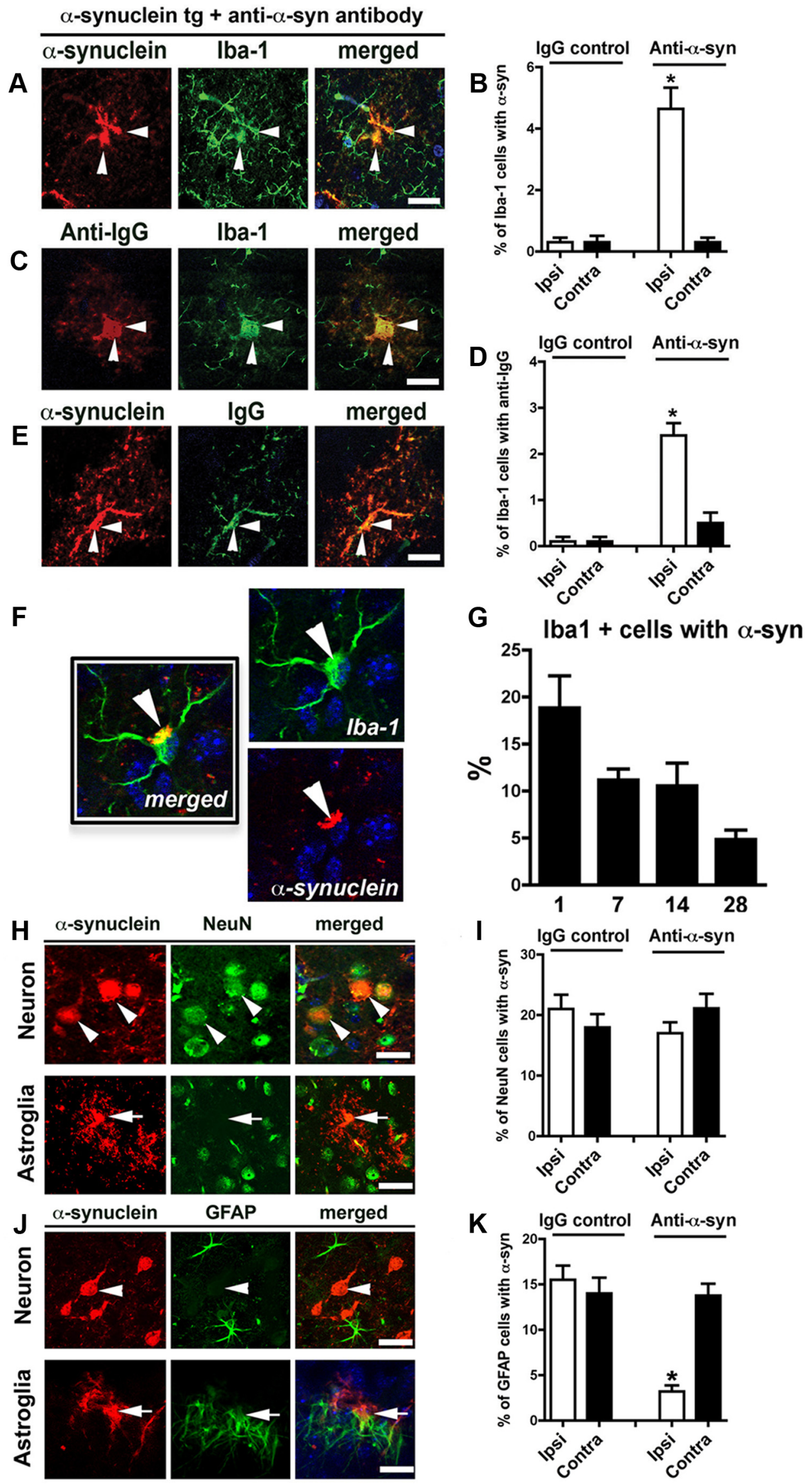

Figure 8. Increased localization of $\alpha$-synuclein and lgG in microglial cells in vivo after unilateral injection of antibodies. PDGF- $\alpha$-synuclein tg mice (line M) received intrahippocampal injection, as in Figure 7. Images in $\boldsymbol{A}-\boldsymbol{E}$ are from the dentate gyrus and in the site ipsilateral to the injection. Scale bar, $10 \mu \mathrm{m}$. $\boldsymbol{A}$, Double labeling with antibodies against (Figure legend continues.) 
Together, these results showed that passive immunization with the 274 antibody reduced the functional deficits in the $\alpha$-synuclein tg mice, and this was accompanied by a reduction in the accumulation of $\alpha$-synuclein in glial and neuronal cells, and amelioration of the neurodegeneration.

\section{Discussion}

In the present study, we show that antibodies against $\alpha$-synuclein promote clearance of extracellular $\alpha$-synuclein aggregates specifically by microglia. When complexed with specific antibodies, $\alpha$-synuclein aggregates are internalized via Fc $\gamma$ receptors on the surface of microglia, and after internalization the immune complexes are transported through a trafficking pathway that is distinct from that for $\alpha$-synuclein aggregates alone, resulting in more efficient delivery to lysosomes. In addition, we show that antibody-mediated clearance of $\alpha$-synuclein prevents cell-to-cell transfer of $\alpha$-synuclein in a tg mice model. These results support the suggestion that $\alpha$-synuclein immunotherapy might exert therapeutic and preventive effects through promotion of microglia-mediated clearance of extracellular $\alpha$-synuclein.

A small amount of $\alpha$-synuclein is released from neuronal cells via exocytosis (Lee et al., 2005), and this release is increased under stress conditions (Jang et al., 2010). Aggregated forms of $\alpha$-synuclein constitute a larger proportion in released proteins than in cytoplasmic proteins (Jang et al., 2010). Neuron-released $\alpha$-synuclein can be transferred in a prionlike manner to neighboring neurons and astrocytes. This aggregate transmission is associated with cell death in neurons and with inflammatory responses in glia (Lee et al., 2010b). In humans, $\alpha$-synuclein has been reported to spread from host tissues to grafted mesencephalic neurons, and this aggregate propagation was associated with functional decline of grafted dopaminergic neurons (Kordower et al., 2008; Li et al., 2008).Together, these findings underscore the role of extracellular $\alpha$-synuclein in disease pathogenesis. In the present study, we show that direct injection of anti- $\alpha$-synuclein antibodies into the hippocampus of $\mathrm{tg}$ mice facilitates uptake of neuronderived $\alpha$-synuclein by microglia, preventing the transfer of neuronal $\alpha$-synuclein to astrocytes. Prevention of cell-to-cell transfer of $\alpha$-synuclein and associated behavioral improve-

\footnotetext{
$\leftarrow$

(Figure legend continued.) $\quad \alpha$-synuclein (red) and microglial marker (lba1, green). B, Image analysis for double labeling for estimation of the proportion of lba-1-positive cells that colocalize with $\alpha$-synuclein. $n=8$ per group, 9 months old. ${ }^{*} p<0.01$ by two-tailed Student's $t$ test, unpaired. C, Double labeling with antibodies against mouse lgG (red) and lba-1 (green). D, Image analysis for double labeling for estimation of the proportion of Iba-1-positive cells that colocalize with mouse lgG ( $n=8$ per group, 9 months old; ${ }^{*} p<0.01$ by two tailed Student's $t$ test, unpaired). $\boldsymbol{E}$, Double labeling with antibodies against mouse $\operatorname{lgG}$ (red) and $\alpha$-synuclein (green). Arrowheads indicate colocalization of two markers in each panel. All images in $\boldsymbol{F}-\boldsymbol{K}$ are from the hippocampus in the site ipsilateral to the injection. $\boldsymbol{F}$, Example of microglia double labeled with antibodies against $\alpha$-synuclein (red) and lba-1 (green). G, Percentage of Iba-1positive cells with $\alpha$-synuclein at $1,7,14$, and $28 \mathrm{~d}$ post injection. $\boldsymbol{H}$, Double labeling with antibodies against $\alpha$-synuclein (red) and neuronal marker (NeuN, green). Arrowheads indicate colocalization in the top, while arrows in the bottom illustrate spindle-shaped $\alpha$-synucleinpositive cell that does not colocalize with NeuN. I, Image analysis for double labeling for estimation of the proportion of NeuN-positive cells that colocalize with $\alpha$-synuclein. $n=8$ per group, 9 months old. J, Double labeling with antibodies against $\alpha$-synuclein (red) and GFAP (green). Arrowheads indicate $\alpha$-synuclein-positive neurons that do not colocalize with GFAP; arrows indicate $\alpha$-synuclein-positive cells that do colocalize with GFAP. $\boldsymbol{K}$, Image analysis for double labeling for estimation of the proportion of GFAP-positive cells that colocalize with antibody against $\alpha$-synuclein ( $n=8$ per group, 9 months old; ${ }^{*} p<0.05$ by one-way ANOVA, post hoc Tukey-Kramer). Scale bars: $\boldsymbol{H}, \boldsymbol{J}, 25 \mu \mathrm{m}$.
}

ment were also achieved with the intraperitoneal injection of the antibody. Our results suggest that efficient clearance of neuron-derived, extracellular $\alpha$-synuclein prevents cell-tocell transmission of $\alpha$-synuclein aggregates, providing the first experimental validation of extracellular forms of $\alpha$-synuclein as a novel therapeutic target.

Extracellular $\alpha$-synuclein proteins released from neuronal cells may normally be cleared by proteolytic degradation in the extracellular space (Sung et al., 2005) or by uptake and subsequent lysosomal degradation by neighboring cells (Lee, 2008; Lee et al., 2008b). Findings from our previous study suggested that microglia is a major scavenger of extracellular aggregates (Lee et al., 2008a); these results were confirmed in the current study as well. A previous report showed that uptake of extracellular $\alpha$-synuclein aggregates into microglia is mediated in part by the scavenger receptor (Zhang et al., 2007). In our study, in the presence of specific antibodies, uptake of $\alpha$-synuclein aggregates is mediated by Fc $\gamma$ receptors, leading to changes in intracellular trafficking pathways and faster degradation. Involvement of microglia in immunotherapy has also been demonstrated by systemic administration of an amyloid- $\beta$ (A $\beta)$ antibody to amyloid precursor protein tg mice (Koenigsknecht-Talboo et al., 2008). Phagocytosis of $\mathrm{A} \beta$-antibody complexes is also mediated by $\mathrm{Fc} \gamma$ receptors (Bard et al., 2000); however, there appear to be other mechanisms in action that do not require Fc $\gamma$ receptors for clearance (Bacskai et al., 2002; Das et al., 2003). Although our results highlight the role of enhanced clearance of extracellular $\alpha$-synuclein aggregates in immunotherapy, alternative mechanisms should not be ruled out. Blockade of self-assembly of $\alpha$-synuclein or interactions with other molecules by antibodies might prevent pathogenic aggregation of this protein (Näsström et al., 2011). Favoring this idea, single chain variable fragments of $\alpha$-synuclein antibodies, lacking the Fc domain, have shown anti-aggregation capacity and protective effects in vitro (Emadi et al., 2007; Lynch et al., 2008).

Our data showed that Ab62 and Ab274 promoted $\alpha$-synuclein clearance via microglial uptake, whereas Ab169 and Ab171 did not. All antibodies against $\alpha$-synuclein are monoclonal antibodies of IgG2a isotype. However, there are differences in epitopes of these antibodies that may explain their ability to clear $\alpha$-synuclein. The epitopes of 62 and 274 antibodies reside in the C-terminal end of $\alpha$-synuclein (120140), while the epitopes of 169 and 171 antibodies require both the C-terminal region (120-140) and the mid region (61-95). Based on the epitope information, we speculate that antigen recognition by Ab169 and Ab171 is, to some extent, sensitive to conformation of $\alpha$-synuclein, whereas Ab62 and Ab274 are entirely sequence specific, hence reacting to all forms of this protein. This ability of Ab62 and Ab274 to recognize all forms of $\alpha$-synuclein may explain why these antibodies are effective in clearing extracellular $\alpha$-synuclein. However, we need more information on the structure of the extracellular $\alpha$-synuclein and the antigen recognition mechanisms of the antibodies to clearly understand the differences in efficiencies in $\alpha$-synuclein clearance.

Recently, Masliah et al. (2011) suggested that passive immunization of $\alpha$-synuclein tg mice with a novel monoclonal antibody, 9E4, reduced behavioral and neuropathological deficits by enhancing the degradation of intraneuronal $\alpha$-synuclein. It is difficult to directly assess the results of the paper in the context of our current study. The 9E4 antibody used in Masliah (2011) recognizes similar epitope (118-126) 

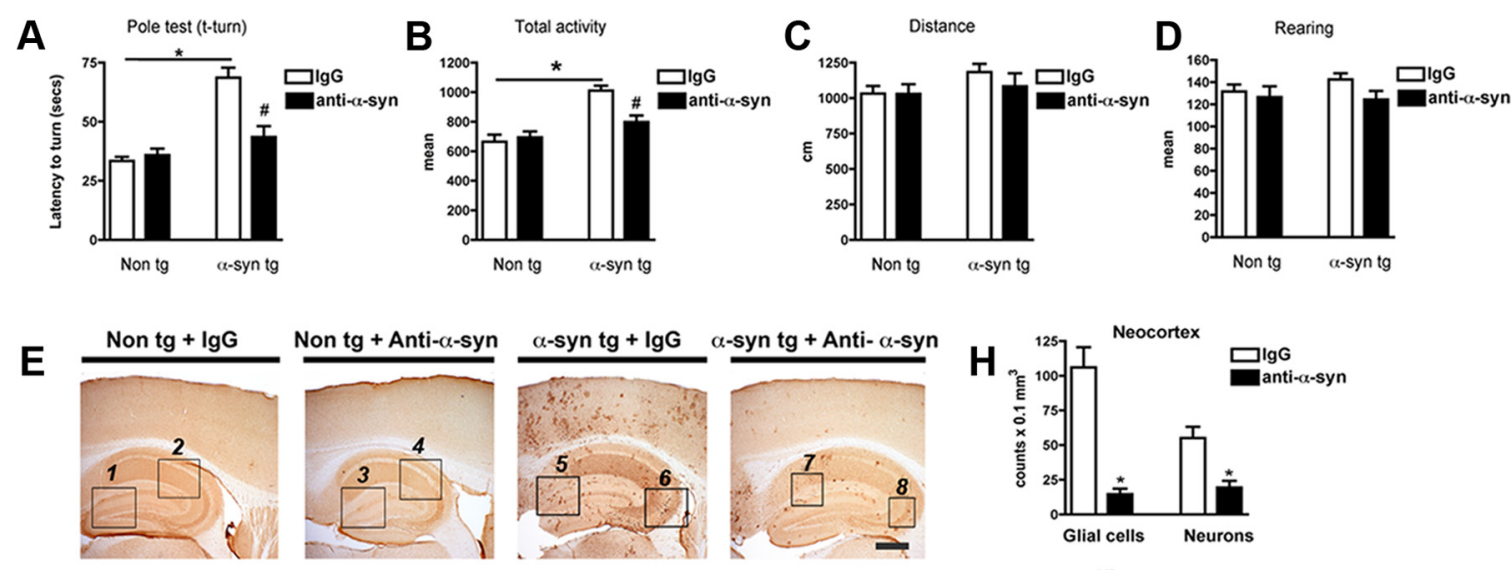

$\mathbf{F}$
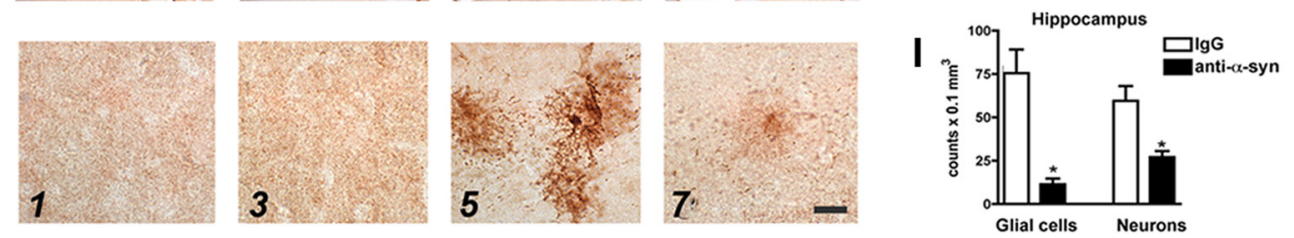

G
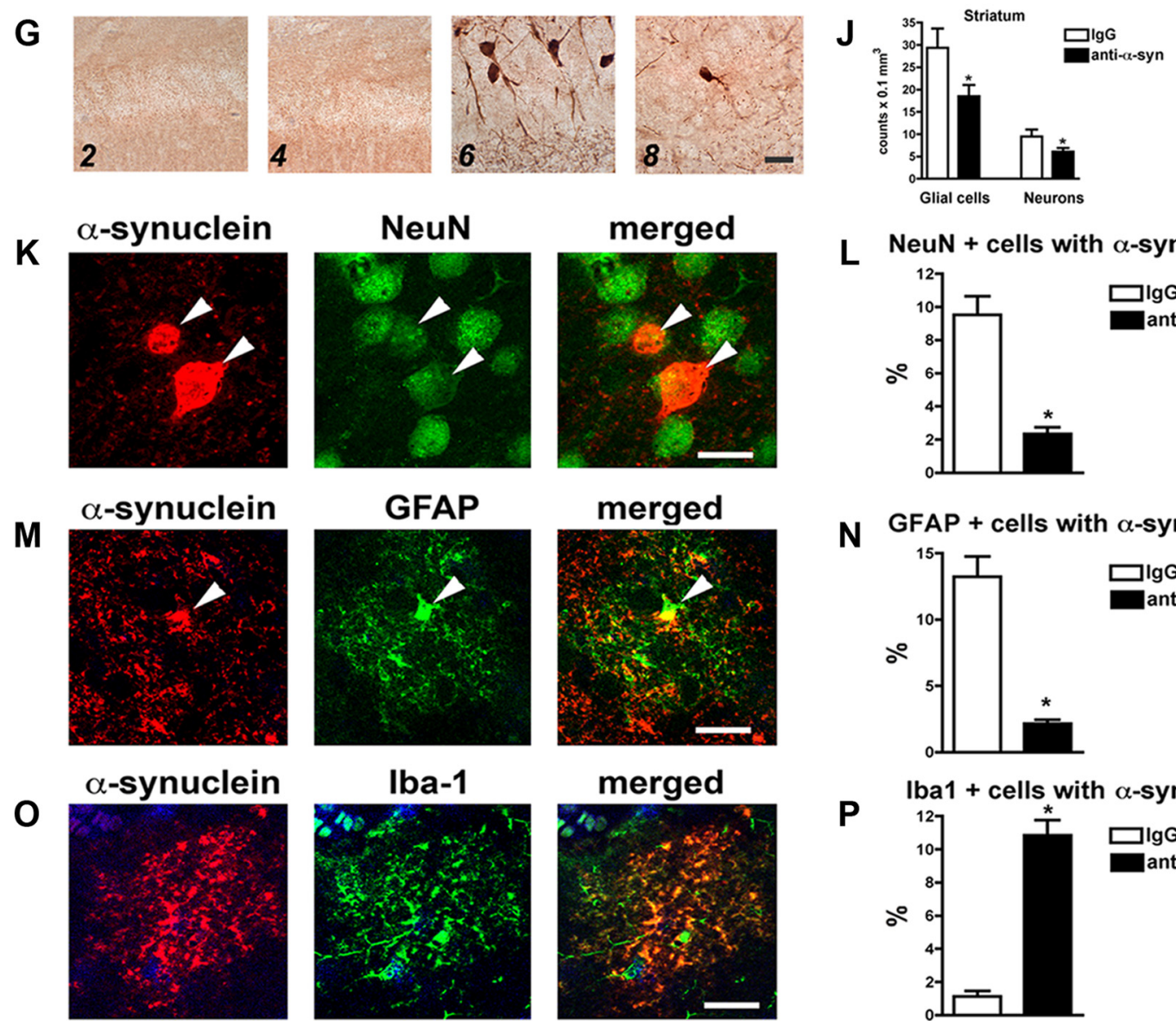

$\mathbf{N}$
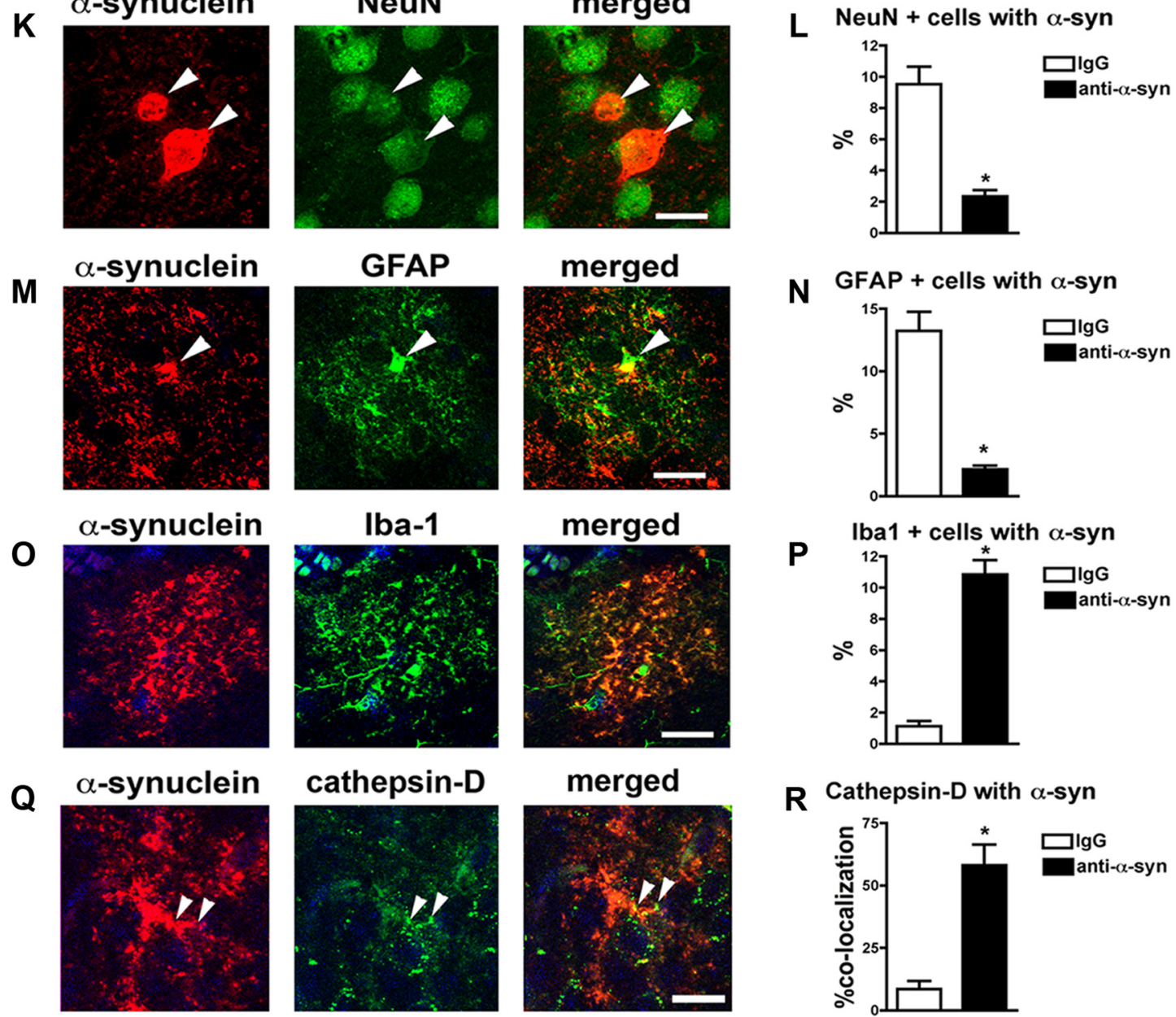

R Cathepsin-D with $\alpha$-syn

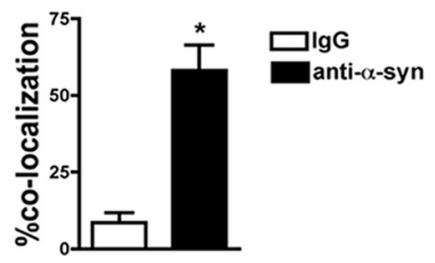

Figure 9. Behavioral improvement and reduced $\alpha$-synuclein deposition in $\alpha$-synuclein tg mice after passive immunization with 274 antibody. $\boldsymbol{A}$, Total time traveled to descend the pole test. $\boldsymbol{B}$, Open field total spontaneous activity (numbers of crosses of photoelectric cell). C, Open field total distance traveled after 5 min of spontaneous activity testing. D, Open field (Figure legend continues.) 
to our Ab274. Masliah et al. (2011) did not present the data on extracellular $\alpha$-synuclein; the uptake and clearance of extracellular $\alpha$-synuclein was not within the scope of the study. In the paper, the role of antibodies in neurons was proposed based on the localization of antibodies in autophagic/lysosomal compartments; the proposal was that antibodies enter into neurons, probably as monomeric antibodies, and enhance the degradation of intraneuronal $\alpha$-synuclein through the autophagic/lysosomal pathway. How antibodies enter into neurons was not addressed in the study. One possibility is that the antibodies may be internalized through the high-affinity receptor, Fc $\gamma$ RI, which, unlike Fc $\gamma$ RIII, can bind to monomeric antibodies (Ravetch and Bolland, 2001). Fc $\gamma$ RI is expressed in certain neurons (Andoh and Kuraishi, 2004; Niu et al., 2011; Qu et al., 2011), whereas Fc $\gamma$ RIII seems to be exclusive in glial cells in the CNS (Niu et al., 2011). Therefore, there may be multiple mechanisms by which antibodies reduce $\alpha$-synuclein burden in the brain; monomeric antibodies can be internalized into neurons through Fc $\gamma \mathrm{RI}$ and reduce the levels of neuronal $\alpha$-synuclein, while antibodies complexed with extracellular $\alpha$-synuclein may clear the protein by enhancing the uptake of the immune complexes into microglia through Fc $\gamma$ RIII.

The rate of uptake of neuronal cell-release $\alpha$-synuclein into the primary microglia was similar to that of oligomeric $\alpha$-synuclein into BV-2; both reached the steady levels in $10 \mathrm{~min}$ (Fig. 3C,F). Although the 274 antibody accelerated the uptake of $\alpha$-synuclein oligomers into both the primary microglia and BV-2 cells, there also was a difference in these cells. The antibody increased both the rate of uptake and the quantity of internalized $\alpha$-synuclein in the steady state in microglia, while in BV-2 cells, only the rate of uptake was increased without changing the steady-state level. The reason for this difference is not clear; however, it might have to do with the relative levels of receptors for $\alpha$-synuclein and Fc $\gamma$ receptors in these cells.

Immunizations against aggregation-prone proteins associated with neurodegenerative diseases have shown promising results; $A \beta$ immunotherapy is the most advanced so far. While early clinical trials of an $A \beta$ vaccine showed adverse side effects, in-

\section{$\leftarrow$}

(Figure legend continued.) total number of rearings after 5 min of spontaneous activity testing. $\boldsymbol{A}-\boldsymbol{D},{ }^{*} p<0.05$ by one-way ANOVA with post hoc Dunnet's when comparing non-tg and $\alpha$-synuclein tg; ${ }^{\#} p<0.05$ by one-way ANOVA with post hoc Fisher when comparing $\lg G$ and 274 antibody in $\alpha$-synuclein tg. E, Low-magnification view $(\times 20)$ of $\alpha$-synuclein immunoreactivity in the cortex and hippocampus. The squares represent the areas magnified in $\boldsymbol{F}$ and $\boldsymbol{G}$. Scale bar, $250 \mu \mathrm{m} . \boldsymbol{F}, \boldsymbol{G}$, Higher magnification ( $\times 630)$ views ( $\boldsymbol{F}$, astrocytes; $\boldsymbol{G}$, neurons). Scale bar, $20 \mu \mathrm{m}$. $\boldsymbol{H}-J$, Image analysis of the estimated numbers (disector method) of glial cells and neuronal cells displaying $\alpha$-synuclein in the neocortex, hippocampus, and striatum, respectively. ${ }^{*} p<0.001$ by Student's $t$ test. $\boldsymbol{K}$, Double labeling with antibodies against $\alpha$-synuclein (red) and neuronal marker (NeuN, green) in hippocampus. Arrowheads indicate colocalization. $L$, Image analysis for double labeling for estimation of the proportion of NeuN-positive cells that colocalize with $\alpha$-synuclein. $M$, Double labeling with antibodies against $\alpha$-synuclein (red) and GFAP (green) in hippocampus. Arrowheads indicate $\alpha$-synuclein-positive cells that colocalize with astroglia. $\boldsymbol{N}$, Image analysis for double labeling for estimation of the proportion of GFAPpositive cells that colocalize with antibody against $\alpha$-synuclein. $\mathbf{O}$, Double labeling with antibodies against $\alpha$-synuclein (red) and lba-1 (green) in hippocampus. Arrowheads indicate $\alpha$-synuclein-positive cells that colocalize with microglia. $\boldsymbol{P}$, Image analysis for double labeling for estimation of the proportion of Iba-1-positive cells that colocalize with antibody against $\alpha$-synuclein. $\mathbf{Q}$, Double labeling with antibodies against $\alpha$-synuclein (red) and cathepsin $\mathbf{D}$ (green) in hippocampus. Arrowheads indicate colocalization. $\boldsymbol{R}$, Image analysis for double labeling for estimation of the proportion of cathepsin-D-positive cells that colocalize with antibody against $\alpha$-synuclein. Scale bar, $10 \mu \mathrm{m} .{ }^{*} p<0.01$ by Student's $t$ test unpaired, twotailed. $n=8$ - to 10-month-old mice. cluding meningoencephalitis (Orgogozo et al., 2003), it also showed clear signs of efficacy, lowering the $\mathrm{A} \beta$ load in the brains of patients (Masliah et al., 2005a; Holmes et al., 2008). Currently, several clinical trials for active and passive immunizations for $\mathrm{A} \beta$ are underway (Lemere and Masliah, 2010). In the case of other disease-linked proteins, such as prion protein, hyperphosphorylated tau, and mutant superoxide dismutase 1 (SOD1), preclinical evidence showed that these proteins can also be targeted for use in immunotherapy (White et al., 2003; Urushitani et al., 2007; Sigurdsson, 2008). However, targeting of proteins, such as $\alpha$-synuclein, tau, and SOD1, still poses a major challenge for immunotherapy due to their localization of neuronal interior. In light of the results presented here, which suggest that immunotherapy can promote clearance of extracellular forms of $\alpha$-synuclein released from neuronal cells, it is reasonable to propose that the efficacy of immunotherapy against tau and SOD1 might also reside in the targeting of extracellular proteins. Tau proteins have been detected in human CSF, and levels of CSF tau were elevated in patients with Alzheimer's disease (AD) when compared with control subjects (Galasko, 1998). Recent studies have shown that tau and SOD1 aggregates can be transmitted from neuron to neuron, making these proteins an attractive target for use in immunotherapy (Clavaguera et al., 2009; Frost et al., 2009; Münch et al., 2011). Therefore, immunotherapy might represent a plausible strategy for management of these diseases, specifically targeting the extracellular forms of aggregation-prone proteins.

Various forms of $\alpha$-synuclein, such as oligomeric and phosphorylated forms, have been detected in human blood plasma and CSF (El-Agnaf et al., 2006; Li et al., 2007; Duran et al., 2010; Foulds et al., 2011). Furthermore, autoantibodies against $\alpha$-synuclein have also been detected in blood sera of PD patients (Papachroni et al., 2007; Patrias et al., 2010; Yanamandra et al., 2011). The levels of antibodies against $\alpha$-synuclein were significantly higher in PD patients compared with controls, and the levels decreased in the late stages of the disease (Yanamandra et al., 2011). These findings suggest the presence of the adaptive immune responses to endogenous pathogenic proteins, perhaps reflecting the attempt to clear these proteins. Therefore, immunization therapy against disease-associated amyloidogenic proteins may use and enhance this already existing adaptive immunity. However, as evidenced by $\mathrm{AD}$ vaccine trials, active immunization against misfolded proteins may elicit adverse immune responses that lead to meningoencephalitis (Orgogozo et al., 2003). To avoid such adverse immune responses, it has been proposed that the regulation of microglial homeostasis may be used to optimize immunization schemes (Kosloski et al., 2010). Alternatively, passive immunization approach may bypass such adverse effects of immunization, yet retain the beneficial effects on aggregate clearance.

Targeting of the extracellular forms of the proteins offers the clear advantage of avoiding interference with the essential functions of the proteins in the neuronal cytoplasm. In cases of $\alpha$-synuclein, evidence suggests selective release of misfolded/ damaged $\alpha$-synuclein proteins from neuronal cells (Jang et al., 2010), perhaps as a mechanism for removal of misfolded proteins, alternative to degradation. Therefore, extracellular diseaseassociated proteins might be novel disease-specific therapeutic targets.

In conclusion, we suggest that extracellular $\alpha$-synuclein aggregates are specific targets for use in successful immunotherapy for PD and other synucleinopathies. In addition, targets such as extracellular $\alpha$-synuclein aggregates might also be used in devel- 

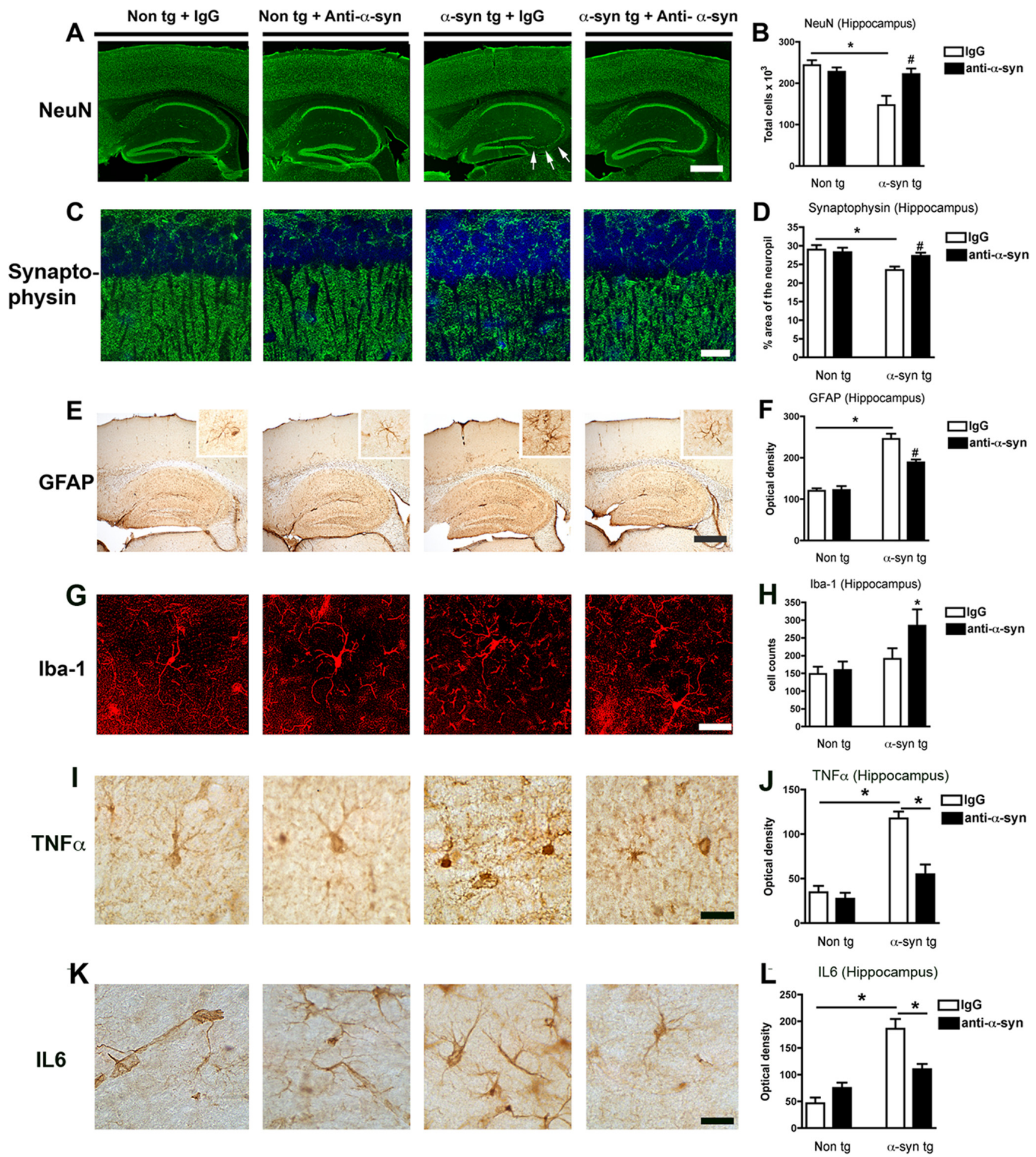

Figure 10. Reduced neurodegeneration and pro-inflammatory cytokines after passive immunization with 274 antibody. $A$, Low-magnification view $(\times 20)$ of sections immunostained with an antibody against NeuN in non-tg and $\alpha$-synuclein tg mice treated with $\lg \mathrm{G}$ or 274 antibody. $\alpha$-synuclein tg mice treated with IgG show neuronal loss in the hippocampus (arrows). Scale bar, 250 $\mu \mathrm{m} . \boldsymbol{B}$, Stereological analysis (disector method) of NeuN in the hippocampus. C, Higher magnification ( $\times 630)$ view of hippocampal sections immunostained with an antibody against synaptophysin in non-tg and $\alpha$-synuclein tg mice treated with the $\mathrm{lgG}$ and 274 antibody respectively, Scale bar, $20 \mu \mathrm{m}$. $\boldsymbol{D}$, Stereological analysis (disector method) of synaptophysin in the hippocampus. $E$, Low-magnification view $(\times 20)$ of sections immunostained with an antibody against GFAP in non-tg and $\alpha$-synuclein tg mice treated with $\lg G$ or 274 antibody. $\alpha$-synuclein tg mice treated with IgG show increased astrogliosis in the neocortex (inset) and hippocampus. Scale bar, $250 \mu \mathrm{m}$. $\boldsymbol{F}$, Image analysis of GFAP immunoreactivity expressed in optical density. The measurements were performed in the whole hippocampus. G, Higher magnification $(\times 630)$ view of hippocampal sections immunostained with an antibody against Iba- 1 in non-tg and $\alpha$-synuclein tg mice treated with the IgG and 274 antibody, respectively. Scale bar, $20 \mu \mathrm{m}$. $\boldsymbol{H}$, Image analysis of the estimated numbers of microglial cells in the hippocampus. ${ }^{*} p<0.05$ by one-way ANOVA with post hoc Dunnet's when comparing non-tg and $\alpha$-synuclein tg; $" p<0.05$ by one-way ANOVA with post hoc Fisher when comparing lgG and 274 antibody in $\alpha$-synuclein tg. I-L, Sections were immunolabeled with antibodies against TNF $\alpha$ and IL-6 and microdensitometric analysis was performed in the hippocampus. Compared with non-tg controls, in the $\alpha$-synuclein tg mice treated with IgG, levels of TNF $\alpha$ $(\boldsymbol{I}, \boldsymbol{J})$ and IL-6 $(\boldsymbol{K}, \boldsymbol{L})$ were elevated, while treatment with the 274 antibody reduced levels of these cytokines in $\alpha$-synuclein $\operatorname{tg}$ mice. ${ }^{*} p<0.05$ by one-way ANOVA with post hoc Dunnet's when comparing non-tg and $\alpha$-synuclein tg and Fisher when comparing treatment groups. 
opment of novel small molecule drugs that mimic the beneficial effects of antibodies without the adverse effects.

\section{References}

Andoh T, Kuraishi Y (2004) Direct action of immunoglobulin G on primary sensory neurons through Fc gamma receptor I. FASEB J 18:182-184.

Bacskai BJ, Kajdasz ST, McLellan ME, Games D, Seubert P, Schenk D, Hyman BT (2002) Non-Fc-mediated mechanisms are involved in clearance of amyloid-beta in vivo by immunotherapy. J Neurosci 22:7873-7878.

Barabé F, Rollet-Labelle E, Gilbert C, Fernandes MJ, Naccache SN, Naccache PH (2002) Early events in the activation of Fc gamma RIIA in human neutrophils: stimulated insolubilization, translocation to detergentresistant domains, and degradation of Fc gamma RIIA. J Immunol 168:4042-4049.

Bard F, Cannon C, Barbour R, Burke RL, Games D, Grajeda H, Guido T, Hu K, Huang J, Johnson-Wood K, Khan K, Kholodenko D, Lee M, Lieberburg I, Motter R, Nguyen M, Soriano F, Vasquez N, Weiss K, Welch B, et al. (2000) Peripherally administered antibodies against amyloid betapeptide enter the central nervous system and reduce pathology in a mouse model of Alzheimer disease. Nat Med 6:916-919.

Clavaguera F, Bolmont T, Crowther RA, Abramowski D, Frank S, Probst A, Fraser G, Stalder AK, Beibel M, Staufenbiel M, Jucker M, Goedert M, Tolnay M (2009) Transmission and spreading of tauopathy in transgenic mouse brain. Nat Cell Biol 11:909-913.

Cookson MR (2009) alpha-Synuclein and neuronal cell death. Mol Neurodegener 4:9.

Danzer KM, Haasen D, Karow AR, Moussaud S, Habeck M, Giese A, Kretzschmar H, Hengerer B, Kostka M (2007) Different species of alphasynuclein oligomers induce calcium influx and seeding. J Neurosci 27:9220-9232.

Danzer KM, Ruf WP, Putcha P, Joyner D, Hashimoto T, Glabe C, Hyman BT, McLean PJ (2011) Heat-shock protein 70 modulates toxic extracellular alpha-synuclein oligomers and rescues trans-synaptic toxicity. FASEB J 25:326-336.

Das P, Howard V, Loosbrock N, Dickson D, Murphy MP, Golde TE (2003) Amyloid-beta immunization effectively reduces amyloid deposition in FcRgamma-/- knock-out mice. J Neurosci 23:8532-8538.

Desplats P, Lee HJ, Bae EJ, Patrick C, Rockenstein E, Crews L, Spencer B, Masliah E, Lee SJ (2009) Inclusion formation and neuronal cell death through neuron-to-neuron transmission of alpha-synuclein. Proc Natl Acad Sci U S A 106:13010-13015.

Duran R, Barrero FJ, Morales B, Luna JD, Ramirez M, Vives F (2010) Plasma alpha-synuclein in patients with Parkinson's disease with and without treatment. Mov Disord 25:489-493.

El-Agnaf OM, Salem SA, Paleologou KE, Cooper LJ, Fullwood NJ, Gibson MJ, Curran MD, Court JA, Mann DM, Ikeda S, Cookson MR, Hardy J, Allsop D (2003) Alpha-synuclein implicated in Parkinson's disease is present in extracellular biological fluids, including human plasma. FASEB J 17:1945-1947.

El-Agnaf OM, Salem SA, Paleologou KE, Curran MD, Gibson MJ, Court JA, Schlossmacher MG, Allsop D (2006) Detection of oligomeric forms of alpha-synuclein protein in human plasma as a potential biomarker for Parkinson's disease. FASEB J 20:419-425.

Emadi S, Barkhordarian H, Wang MS, Schulz P, Sierks MR (2007) Isolation of a human single chain antibody fragment against oligomeric alphasynuclein that inhibits aggregation and prevents alpha-synuclein-induced toxicity. J Mol Biol 368:1132-1144.

Emmanouilidou E, Melachroinou K, Roumeliotis T, Garbis SD, Ntzouni M, Margaritis LH, Stefanis L, Vekrellis K (2010) Cell-produced alphasynuclein is secreted in a calcium-dependent manner by exosomes and impacts neuronal survival. J Neurosci 30:6838-6851.

Foulds PG, Mitchell JD, Parker A, Turner R, Green G, Diggle P, Hasegawa M, Taylor M, Mann D, Allsop D (2011) Phosphorylated alpha-synuclein can be detected in blood plasma and is potentially a useful biomarker for Parkinson's disease. FASEB J 25:4127-4137.

Franklin KBJ, Paxinos G, (2008) The mouse brain in stereotaxic coordinates, Ed 3. Burlington, MA: Elsevier.

Frost B, Jacks RL, Diamond MI (2009) Propagation of tau misfolding from the outside to the inside of a cell. J Biol Chem 284:12845-12852.

Galasko D (1998) CSF tau and Abeta42: logical biomarkers for Alzheimer's disease? Neurobiol Aging 19:117-119.
Gessner JE, Heiken H, Tamm A, Schmidt RE (1998) The IgG Fc receptor family. Ann Hematol 76:231-248.

Hansen C, Angot E, Bergström AL, Steiner JA, Pieri L, Paul G, Outeiro TF, Melki R, Kallunki P, Fog K, Li JY, Brundin P (2011) alpha-Synuclein propagates from mouse brain to grafted dopaminergic neurons and seeds aggregation in cultured human cells. J Clin Invest 121:715-725.

Holmes C, Boche D, Wilkinson D, Yadegarfar G, Hopkins V, Bayer A, Jones RW, Bullock R, Love S, Neal JW, Zotova E, Nicoll JA (2008) Long-term effects of Abeta42 immunisation in Alzheimer's disease: follow-up of a randomised, placebo-controlled phase I trial. Lancet 372:216-223.

Iwai A, Masliah E, Yoshimoto M, Ge N, Flanagan L, de Silva HA, Kittel A, Saitoh T (1995) The precursor protein of non-A beta component of Alzheimer's disease amyloid is a presynaptic protein of the central nervous system. Neuron 14:467-475.

Jang A, Lee HJ, Suk JE, Jung JW, Kim KP, Lee SJ (2010) Non-classical exocytosis of alpha-synuclein is sensitive to folding states and promoted under stress conditions. J Neurochem 113:1263-1274.

Koenigsknecht-Talboo J, Meyer-Luehmann M, Parsadanian M, Garcia-Alloza M, Finn MB, Hyman BT, Bacskai BJ, Holtzman DM (2008) Rapid microglial response around amyloid pathology after systemic anti-Abeta antibody administration in PDAPP mice. J Neurosci 28:14156-14164.

Kordower JH, Chu Y, Hauser RA, Freeman TB, Olanow CW (2008) Lewy body-like pathology in long-term embryonic nigral transplants in Parkinson's disease. Nat Med 14:504-506.

Kordower JH, Dodiya HB, Kordower AM, Terpstra B, Paumier K, Madhavan L, Sortwell C, Steece-Collier K, Collier TJ (2011) Transfer of hostderived alpha synuclein to grafted dopaminergic neurons in rat. Neurobiol Dis 43:552-557.

Kosloski LM, Ha DM, Hutter JA, Stone DK, Pichler MR, Reynolds AD, Gendelman HE, Mosley RL (2010) Adaptive immune regulation of glial homeostasis as an immunization strategy for neurodegenerative diseases. J Neurochem 114:1261-1276.

Kwiatkowska K, Frey J, Sobota A (2003) Phosphorylation of FcgammaRIIA is required for the receptor-induced actin rearrangement and capping: the role of membrane rafts. J Cell Sci 116:537-550.

Lee HJ, Lee SJ (2002) Characterization of cytoplasmic alpha-synuclein aggregates. Fibril formation is tightly linked to the inclusion-forming process in cells. J Biol Chem 277:48976-48983.

Lee HJ, Khoshaghideh F, Patel S, Lee SJ (2004) Clearance of alpha-synuclein oligomeric intermediates via the lysosomal degradation pathway. J Neurosci 24:1888-1896.

Lee HJ, Patel S, Lee SJ (2005) Intravesicular localization and exocytosis of alpha-synuclein and its aggregates. J Neurosci 25:6016-6024.

Lee HJ, Suk JE, Bae EJ, Lee SJ (2008a) Clearance and deposition of extracellular alpha-synuclein aggregates in microglia. Biochem Biophys Res Commun 372:423-428.

Lee HJ, Suk JE, Bae EJ, Lee JH, Paik SR, Lee SJ (2008b) Assembly-dependent endocytosis and clearance of extracellular alpha-synuclein. Int J Biochem Cell Biol 40:1835-1849.

Lee HJ, Suk JE, Patrick C, Bae EJ, Cho JH, Rho S, Hwang D, Masliah E, Lee SJ (2010a) Direct transfer of alpha-synuclein from neuron to astroglia causes inflammatory responses in synucleinopathies. J Biol Chem 285:9262-9272.

Lee HJ, Baek SM, Ho DH, Suk JE, Cho ED, Lee SJ (2011a) Dopamine promotes formation and secretion of non-fibrillar alpha-synuclein oligomers. Exp Mol Med 43:216-222.

Lee HJ, Bae EJ, Jang A, Ho DH, Cho ED, Suk JE, Yun YM, Lee SJ (2011b) Enzyme-linked immunosorbent assays for alpha-synuclein with species and multimeric state specificities. J Neurosci Methods 199:249-257.

Lee SJ (2008) Origins and effects of extracellular alpha-synuclein: implications in Parkinson's disease. J Mol Neurosci 34:17-22.

Lee SJ, Lee HJ, Masliah E (2010b) Multiple non-cell autonomous actions of alpha-synuclein in neurodegenerative diseases: Is there a direct link? Cell Cycle 9:2696-2697.

Lee SJ, Desplats P, Sigurdson C, Tsigelny I, Masliah E (2010c) Cell-to-cell transmission of non-prion protein aggregates. Nat Rev Neurol 6:702-706.

Lee SJ, Lim HS, Masliah E, Lee HJ (2011c) Protein aggregate spreading in neurodegenerative diseases: Problems and perspectives. Neurosci Res 70:339-348.

Lemere CA, Masliah E (2010) Can Alzheimer disease be prevented by amyloid-beta immunotherapy? Nat Rev Neurol 6:108-119.

Li JY, Englund E, Holton JL, Soulet D, Hagell P, Lees AJ, Lashley T, Quinn NP, 
Rehncrona S, Björklund A, Widner H, Revesz T, Lindvall O, Brundin P (2008) Lewy bodies in grafted neurons in subjects with Parkinson's disease suggest host-to-graft disease propagation. Nat Med 14:501-503.

Li QX, Mok SS, Laughton KM, McLean CA, Cappai R, Masters CL, Culvenor JG, Horne MK (2007) Plasma alpha-synuclein is decreased in subjects with Parkinson's disease. Exp Neurol 204:583-588.

Lynch SM, Zhou C, Messer A (2008) An scFv intrabody against the nonamyloid component of alpha-synuclein reduces intracellular aggregation and toxicity. J Mol Biol 377:136-147.

Masliah E, Rockenstein E, Veinbergs I, Mallory M, Hashimoto M, Takeda A, Sagara Y, Sisk A, Mucke L (2000) Dopaminergic loss and inclusion body formation in alpha-synuclein mice: implications for neurodegenerative disorders. Science 287:1265-1269.

Masliah E, Hansen L, Adame A, Crews L, Bard F, Lee C, Seubert P, Games D, Kirby L, Schenk D (2005a) Abeta vaccination effects on plaque pathology in the absence of encephalitis in Alzheimer disease. Neurology 64:129-131.

Masliah E, Rockenstein E, Adame A, Alford M, Crews L, Hashimoto M, Seubert P, Lee M, Goldstein J, Chilcote T, Games D, Schenk D (2005b) Effects of alpha-synuclein immunization in a mouse model of Parkinson's disease. Neuron 46:857-868.

Masliah E, Rockenstein E, Mante M, Crews L, Spencer B, Adame A, Patrick C, Trejo M, Ubhi K, Rohn TT, Mueller-Steiner S, Seubert P, Barbour R, McConlogue L, Buttini M, Games D, Schenk D (2011) Passive immunization reduces behavioral and neuropathological deficits in an alphasynuclein transgenic model of Lewy body disease. PLoS One 6:e19338.

Mollenhauer B, El-Agnaf OM, Marcus K, Trenkwalder C, Schlossmacher MG (2010) Quantification of alpha-synuclein in cerebrospinal fluid as a biomarker candidate: review of the literature and considerations for future studies. Biomark Med 4:683-699.

Münch C, O'Brien J, Bertolotti A (2011) Prion-like propagation of mutant superoxide dismutase-1 misfolding in neuronal cells. Proc Natl Acad Sci U S A 108:3548-3553.

Näsström T, Gonçalves S, Sahlin C, Nordström E, Screpanti Sundquist V, Lannfelt L, Bergström J, Outeiro TF, Ingelsson M (2011) Antibodies against alpha-synuclein reduce oligomerization in living cells. PLoS One 6:e27230.

Niu N, Zhang J, Guo Y, Zhao Y, Korteweg C, Gu J (2011) Expression and distribution of immunoglobulin $\mathrm{G}$ and its receptors in the human nervous system. Int J Biochem Cell Biol 43:556-563.

Orgogozo JM, Gilman S, Dartigues JF, Laurent B, Puel M, Kirby LC, Jouanny P, Dubois B, Eisner L, Flitman S, Michel BF, Boada M, Frank A, Hock C (2003) Subacute meningoencephalitis in a subset of patients with AD after Abeta42 immunization. Neurology 61:46-54.

Papachroni KK, Ninkina N, Papapanagiotou A, Hadjigeorgiou GM, Xiromerisiou G, Papadimitriou A, Kalofoutis A, Buchman VL (2007) Autoantibodies to alpha-synuclein in inherited Parkinson's disease. J Neurochem 101:749-756.

Patrias LM, Klaver AC, Coffey MP, Loeffler DA (2010) Specific antibodies to soluble alpha-synuclein conformations in intravenous immunoglobulin preparations. Clin Exp Immunol 161:527-535.

Price DL, Rockenstein E, Ubhi K, Phung V, MacLean-Lewis N, Askay D,
Cartier A, Spencer B, Patrick C, Desplats P, Ellisman MH, Masliah E (2010) Alterations in mGluR5 expression and signaling in Lewy body disease and in transgenic models of alpha-synucleinopathy-implications for excitotoxicity. PLoS One 5:e14020.

Qu L, Zhang P, LaMotte RH, Ma C (2011) Neuronal Fc-gamma receptor I mediated excitatory effects of $\operatorname{IgG}$ immune complex on rat dorsal root ganglion neurons. Brain Behav Immun 25:1399-1407.

Radaev S, Sun P (2002) Recognition of immunoglobulins by Fcgamma receptors. Mol Immunol 38:1073-1083.

Ravetch JV, Bolland S (2001) IgG Fc receptors. Annu Rev Immunol 19:275-290.

Rockenstein E, Mallory M, Hashimoto M, Song D, Shults CW, Lang I, Masliah E (2002) Differential neuropathological alterations in transgenic mice expressing alpha-synuclein from the platelet-derived growth factor and Thy-1 promoters. J Neurosci Res 68:568-578.

Rollet-Labelle E, Marois S, Barbeau K, Malawista SE, Naccache PH (2004) Recruitment of the cross-linked opsonic receptor CD32A (FcgammaRIIA) to high-density detergent-resistant membrane domains in human neutrophils. Biochem J 381:919-928.

Sharma DK, Brown JC, Choudhury A, Peterson TE, Holicky E, Marks DL, Simari R, Parton RG, Pagano RE (2004) Selective stimulation of caveolar endocytosis by glycosphingolipids and cholesterol. Mol Biol Cell 15:3114-3122.

Sigurdsson EM (2008) Immunotherapy targeting pathological tau protein in Alzheimer's disease and related tauopathies. J Alzheimers Dis 15:157-168.

Spencer B, Potkar R, Trejo M, Rockenstein E, Patrick C, Gindi R, Adame A, Wyss-Coray T, Masliah E (2009) Beclin 1 gene transfer activates autophagy and ameliorates the neurodegenerative pathology in alphasynuclein models of Parkinson's and Lewy body diseases. J Neurosci 29:13578-13588.

Sung JY, Park SM, Lee CH, Um JW, Lee HJ, Kim J, Oh YJ, Lee ST, Paik SR, Chung KC (2005) Proteolytic cleavage of extracellular secreted \{alpha\}synuclein via matrix metalloproteinases. J Biol Chem 280:25216-25224.

Urushitani M, Ezzi SA, Julien JP (2007) Therapeutic effects of immunization with mutant superoxide dismutase in mice models of amyotrophic lateral sclerosis. Proc Natl Acad Sci U S A 104:2495-2500.

White AR, Enever P, Tayebi M, Mushens R, Linehan J, Brandner S, Anstee D, Collinge J, Hawke S (2003) Monoclonal antibodies inhibit prion replication and delay the development of prion disease. Nature 422:80-83.

Wijngaarden S, van Roon JA, van de Winkel JG, Bijlsma JW, Lafeber FP (2005) Down-regulation of activating Fcgamma receptors on monocytes of patients with rheumatoid arthritis upon methotrexate treatment. Rheumatology 44:729-734.

Yanamandra K, Gruden MA, Casaite V, Meskys R, Forsgren L, MorozovaRoche LA (2011) alpha-synuclein reactive antibodies as diagnostic biomarkers in blood sera of Parkinson's disease patients. PLoS One 6:e18513.

Zhang W, Dallas S, Zhang D, Guo JP, Pang H, Wilson B, Miller DS, Chen B, Zhang W, McGeer PL, Hong JS, Zhang J (2007) Microglial PHOX and Mac-1 are essential to the enhanced dopaminergic neurodegeneration elicited by A30P and A53T mutant alpha-synuclein. Glia 55:1178-1188. 